\title{
New insights into the reproductive cycle of two Great Scallop populations in Brittany (France) using a DEB modelling approach
}

\author{
Gourault Mélaine ${ }^{4,{ }^{*}}$, Lavaud Romain ${ }^{2}$, Leynaert Aude ${ }^{3}$, Pecquerie Laure ${ }^{3}$, Paulet Yves-Marie ${ }^{3}$, \\ Pouvreau Stéphane ${ }^{1}$
}

${ }^{1}$ Ifremer, Laboratoire des Sciences de l'Environnement Marin (LEMAR), 29840 Argenton-en-

Landunvez, France

${ }^{2}$ Fisheries and Oceans Canada, Moncton, NB E1C 9B6, Canada

${ }^{3}$ Laboratoire des Sciences de l'Environnement Marin (LEMAR), UBO, CNRS, IRD, Ifremer, Plouzané, France

* Corresponding author : Mélaine Gourault, email address : melaine.gourault@gmail.com

\begin{abstract}
:
The present study aimed to improve understanding of the environmental conditions influencing the reproductive cycle of the great scallop Pecten maximus in two locations in Brittany (France). We also evaluated potential consequences of future climate change for reproductive success in each site.

We simulated reproductive traits (spawning occurrences and synchronicity among individuals) of $P$. maximus, using an existing Dynamic Energy Budget (DEB) model. To validate and test the model, we used biological and environmental datasets available for the Bay of Brest (West Brittany, France) between 1998 and 2003. We also applied the scallop DEB model in the Bay of Saint-Brieuc (North Brittany, France) for the same period (1998-2003) to compare the reproductive cycle in different environmental conditions. In order to accurately model the $P$. maximus reproductive cycle we improved the scallop DEB model in two ways: through (1) energy acquisition, by incorporating microphytobenthos as a new food source; and (2) the reproductive process, by adding a new state variable dedicated to the gamete production. Finally, we explored the effects of two contrasting IPCC climate scenarios (RCP2.6 and RCP8.5) on the reproductive cycle of $P$. maximus in these two areas at the 2100 horizon.
\end{abstract}

In the Bay of Brest, the simulated reproductive cycle was in agreement with field observations. The model reproduced three main spawning events every year (between May and September) and asynchronicity in the timing of spawning between individuals. In the Bay of Saint-Brieuc, only two summer spawning events (in July and August) were simulated, with a higher synchronicity between individuals. Environmental conditions (temperature and food sources) were sufficient to explain this well-known geographic difference in the reproductive strategy of $P$. maximus. Regarding the forecasting approach, the model showed that, under a warm scenario (RCP8.5), autumnal spawning would be enhanced at the 2100 horizon with an increase of seawater temperature in the Bay of Brest, whatever the food source conditions. In the Bay of Saint-Brieuc, warmer temperatures may impact reproductive 
phenology through an earlier onset of spawning by 20 to 44 days depending on the year.

\section{Highlights}

- We aimed at better understanding and quantifying the effect of environmental variables (temperature and food sources) on the reproduction variability of the Great Scallop Pecten maximus in Brittany. We improved an existing scallop-DEB model at two different levels, by adding a new food source and a more detailed reproduction module. We compared reproductive traits of the Great Scallop in two Brittany locations for the period 1998-2003 and we made forecasts at the 2100 horizon within a context of ocean warming. We evidenced two different effects of the increase of seawater temperature depending on the location: a most efficient autumnal last spawning in the Bay of Brest and an earlier onset of spawning in the Bay of Saint-Brieuc.

Keywords : Pecten maximus, DEB theory, reproduction cycle, IPCC scenarios, Bay of Brest, Bay of Saint-Brieuc 
The great scallop, Pecten maximus (Linnaeus, 1758) inhabits many sublittoral environments along Northeast Atlantic coasts from northern Norway to the Iberian Peninsula (Ansell et al., 1991). In France, the species is particularly abundant along the coast of northern Brittany, where it sustains one of the most important French commercial fisheries both in terms of landings and of socio-economic value (more than 300 fishing boats; ICES, 2015). The main fishing areas are located in the Bay of Brest, connected to the Iroise Sea, and in the Bay of Saint-Brieuc, open to the English Channel (Fig. 1). While some of the highest scallop densities are found in the Bay of Saint-Brieuc, in part due to sustainable exploitation measures, the scallop stock in the Bay of Brest is lower and highly dependent on hatchery produced spat since 1983.

From a biological point of view, scallops, like most other bivalves, are filter feeders and consume phytoplankton. However, since they live settled into the surface layer of the bottom, they are also thought to use the epibenthic layer as an important food source (see review in Shumway, 1990). Concerning the reproductive cycle, $P$. maximus is a functional hermaphrodite species, it has a pelagic larval stage during approximately one month after fertilization, switching to a benthic life after metamorphosis. Its reproductive strategy is more surprising as its spawning period varies according to the geographical location of the population (see review by Gosling (2004)) There can be between one major summer spawning and more than three spawnings in the period from spring to early autumn. At a small regional scale, geographical differences can be very marked: scallops from the Bay of Brest show low inter-individual synchronism, with multiple partial spawnings from early spring to autumn and almost no resting stage, whereas the population from the Bay of St-Brieuc is almost synchronous, with one or two major spawnings over a short period (July-August), with a sexual rest stage then observed in autumn and winter (e.g. Devauchelle and Mingant, 1991; Paulet et al., 1997).

A major part of this phenotypic variability has been attributed to differences in environmental conditions such as food sources, temperature and photoperiod, which are known to influence gametogenesis and fecundity in marine invertebrates. For example, Claereboudt and Himmelman (1996) showed that an increase in temperature and food availability increased reproductive effort in 
Placopecten magellanicus. In P. maximus, quantity and quality of food sources also have an impact on hatching rate (Soudant et al., 1996), and laboratory experiments showed that spring conditions (regular increase of temperature and photoperiod) favoured gonad growth, whereas winter conditions (regular decrease of temperature and daylight duration) were associated with somatic growth of the adductor muscle and digestive gland (Saout et al., 1999; Lorrain et al., 2002). More recently, Chauvaud et al., (2012) and Lavaud et al. (2014) have proposed complementary approaches to quantitatively evaluate effects on environmental factors on growth and reproduction of scallops. However, the relative importance of these variables remains difficult to disentangle, especially under natural conditions.

Climate models and observations to date indicate that the Earth will warm between two (IPCC scenario RCP2.6) and six degrees Celsius (IPCC scenario RCP8.5) over the next century, depending on how fast carbon dioxide emissions increase. The ocean absorbs most of this excess heat, leading to rising seawater temperatures (e.g., IPCC, 2014; Appendix A). Increasing ocean temperatures will deeply affect marine species and ecosystems. Understanding the potential effects of climate change on the timing of life-history events such as the onset of gametogenesis, spawning, hatching and larval metamorphosis is important for benthic ecology but also for aquaculture and fisheries production. The phenology of these key life-history events has been investigated in several ecosystems and in many species (e.g., Beukema et al., 2009; Menge et al., 2009; Shephard et al., 2010; Valdizan et al., 2011; Morgan et al., 2013), although these studies often had limited spatial and/or temporal resolution. Mechanistic modelling provides a complementary tool to analyse climate effects on life-history traits, identify interactions between multiple stressors, and make predictions about future condition scenarios at a larger spatiotemporal scale. In recent decades, bivalve growth and reproduction have been successfully modelled (e.g. Bernard et al., 2011; Thomas et al., 2016; Montalto et al., 2017; Gourault et al, 2018, this issue) using mechanistic models based on Dynamic Energy Budget theory (DEB; Kooijman, 2010). This theory makes it possible to quantify the energy flows within an individual from ingestion to maintenance, growth, development, and reproduction in relation to environmental conditions. 
101 influencing the reproductive cycle of $P$. maximus using a DEB model and the potential effects of

102 climate change on the reproductive activity of this species. Our work is based on an existing DEB

103 model developed for the great scallop in the Bay of Brest (Lavaud et al. 2014) that we then improved

104 by adding detail on the reproductive processes. To evaluate the ability of the model to simulate

105 reproductive processes under various conditions, we tested it over six years in the Bay of Brest (1998-

106 2003) and in the two main locations hosting scallop populations in Brittany: the Bay of Brest and the

107 Bay of Saint-Brieuc. In a second step, using two IPCC climate scenarios at the 2100 horizon, we

108 examined the potential consequences of future climate change on the reproductive activity of this

109 emblematic species in each of the two sites. 


\section{Material and Methods}

\subsection{Study sites}

The Bay of Brest is a semi-enclosed coastal ecosystem located in western Brittany, France, connected to the Atlantic Ocean by a deep narrow strait. The bay itself covers an area of nearly 180 $\mathrm{km}^{2}$, with an average depth of $8 \mathrm{~m}$. Two rivers flow into the bay: the Elorn (watershed of $402 \mathrm{~km}^{2}$ ) and the Aulne (watershed of $1842 \mathrm{~km}^{2}$ ) (Fig. 1). Temperature and phytoplankton concentration are continuously monitored at two locations in the Bay: Lanvéoc station in the southern part of the Bay (data provided by the REPHY network - Phytoplankton and Phycotoxin monitoring NEtwork, Ifremer, e.g. Belin et al., 2017) and Sainte-Anne station in the north-western part (data provided by the SOMLIT - "Service d'Observation en Milieu Littoral”, INSU-CNRS, Brest). Lanvéoc station (48²9' $\mathrm{N}, 04^{\circ} 46^{\prime} \mathrm{W}$; Fig. 1) has a depth range of 6 to $9 \mathrm{~m}$ at lowest spring tides and a bottom composed of sandy mud, with broken shells and pebbles. Sainte-Anne station is located at the entrance to the Bay of Brest $\left(48^{\circ} 21^{\prime \prime}\right.$ N, $04^{\circ} 33$ W; Fig. 1).

The Bay of Saint-Brieuc is located in northern Brittany (France), $150 \mathrm{~km}$ from the Bay of Brest $\left(48^{\circ} 32 \mathrm{~N}, 02^{\circ} 40 \mathrm{~W}\right.$; Fig. 1), in the western part of the English Channel. This bay of $800 \mathrm{~km}^{2}$ harbours a large wild scallop population in its inshore shallow waters $(\leq 30 \mathrm{~m})$. It is subject to an extreme tidal regime with a tidal range between $4 \mathrm{~m}$ at neap tides and nearly $13 \mathrm{~m}$ during spring tides. Seawater temperature and phytoplankton concentration are monitored at the Bréhat station located in the western part of the bay (Fig. 1). 


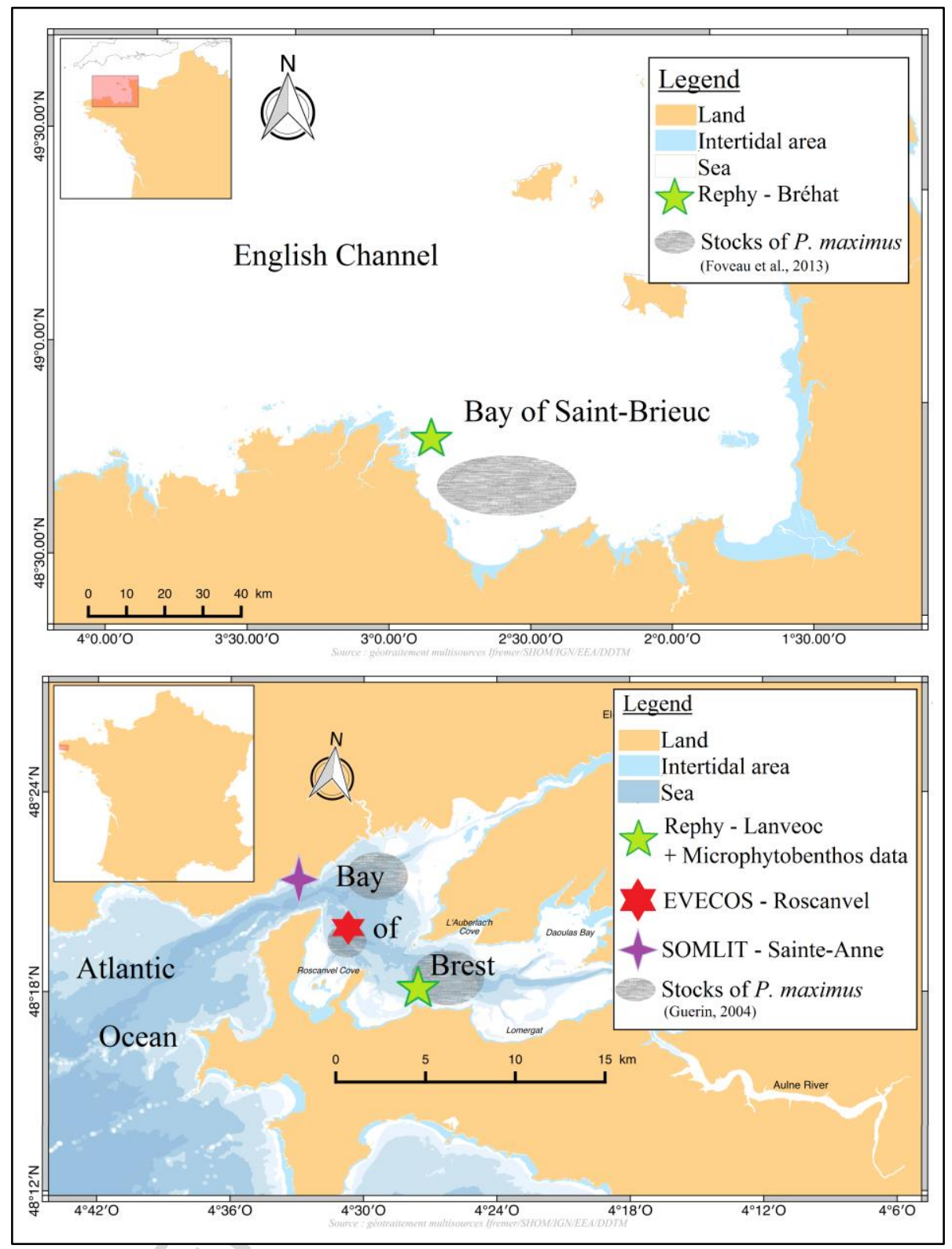

Figure 1: Maps of the two study sites, the Bay of Saint-Brieuc and the Bay of Brest, showing the position of the bimonthly great scallop monitoring area of (EVECOS) and the three environmental monitoring sites: the REPHY stations at Lanvéoc and Bréhat and the SOMLIT station at Sainte-Anne.

\subsection{Scallop biological data}

134 Scallop growth and reproduction were monitored from 1998 to 2003 at Roscanvel in the west of 135 the Bay of Brest $\left(48^{\circ} 20^{\prime} \mathrm{N}, 04^{\circ} 30^{\prime} \mathrm{W}\right.$; Fig. 1). This site, known to host the highest density of $P$. 136 maximus in the bay, is characterized by mixed sandy and silty sediments. It was integrated into a multi-annual monitoring network (EVECOS database provided by the "Observatoire Marin de 
l'IUEM, Brest, France"). A sample of 20 adult scallops (3 years old) was collected by dredging on a

139 biweekly to monthly basis in 30-m deep waters. The scallops were brought back to the laboratory

140 where the muscle, gonads and digestive gland were dissected out. Total wet flesh mass and total dry

141 flesh mass (DFM) of each organ were measured for each individual. In order to compare masses 142 obtained for different sized scallops, dry mass was standardized following the formula of Bayne et al. 143 (1987):

$144 \quad W_{r}=\left(\frac{L_{r}}{L_{m}}\right)^{3} W_{m}$

145 where $W_{r}$ is the standardized mass of an individual of standard shell height $L_{r}$ and $W_{m}$ is the measured 146 mass of an individual of measured shell height $L_{m}$. Length and mean daily shell growth rate (DSGR) 147 were measured according to the method proposed by Chauvaud et al. (2012) (see Lavaud et al. 2014 148 for more detailed information on these data).

Additionally, four additional $P$. maximus reproductive cycle traits were recorded through EVECOS monitoring: the onset of gametogenesis, the number and timing of each main spawning within the reproductive season and the reproductive investment (DFM difference before and after spawning).

\subsection{The scallop DEB model}

The scallop DEB model was derived from the standard DEB model described by Kooijman (2010) and first applied to P. maximus by Lavaud et al. (2014). The DEB model is a mechanistic model that describes the dynamics of three state variables: $\mathrm{E}$, the energy in reserve, $\mathrm{V}$, the volume of structure, and $\mathrm{E}_{\mathrm{R}}$, the energy allocated to development and reproduction. To improve the accuracy with which DEB models model reproductive activity, Bernard et al. (2011) refined the processes of energy allocation to gametogenesis and resorption in the model, such that a fourth state variable, $\mathrm{E}_{\mathrm{GO}}$, the energy in gametes, was added to the existing scallop DEB model (Fig. 2). Briefly, the model can be explained as follows: the reserve mobilization rate, $\dot{p}_{C 1}$, is divided into two parts. A first constant fraction, ??, is allocated to structural growth and maintenance and the remainder, 1-??, is allocated to development (in juveniles), reproduction (in adults) and maturity maintenance. Energy allocation to 
gonad construction is modelled through the gamete mobilization rate, $\dot{p}_{C 2}$. Priority in energy allocation is always given to maintenance costs: $\dot{p}_{M 1}$ for maturity maintenance and $\dot{p}_{J}$ for somatic maintenance. During starvation periods, the gametogenesis flux is re-allocated to somatic and maturity maintenance through secondary maintenance, $\dot{p}_{M 2}$. If $\dot{p}_{M 2}$ does not provide enough energy to cover all maintenance costs, the gamete resorption rate, $\dot{p}_{L 2}$, is activated. In case of extreme starvation, structure can be broken down at the rate $\dot{p}_{L 1}$. The corresponding set of equations can be found in Gourault et al. (2018, this issue).

Regarding food assimilation, a classical scaled functional response (Holling type II) is generally calculated in the model (Kooijman, 2010), using one food source (for bivalves, this essentially consists of phytoplankton cells). However, many studies focusing on modelling the energy dynamics of filter feeders have shown the need and benefit of adding a second food source to improve the food proxy (Alunno-Bruscia et al, 2011; Bernard et al., 2011; Saraiva et al., 2011). Lavaud et al. (2014) included the Synthesizing Units (SUs) concept (Kooijman, 2010; Saraiva et al. 2011) into the scallop DEB model to consider selection of particles based on their size and/or quality. The equations for the SU concept can be found in Lavaud et al. (2014).

In this study we compared the previous model of Lavaud et al. (2014), hereafter referred to as "Mod-1", with our DEB model (with the extra state variable $\mathrm{E}_{\mathrm{GO}}$ ), hereafter referred to as "Mod-2" (Table 1). Two versions of the Mod-2 model were used in order to test different food sources in the model: (1) phytoplankton as a first food proxy and particulate organic matter (POM) as a second food proxy (Mod-2A) and (2) a mix of microphytobenthos and phytoplankton as a first food proxy and POM as a second food proxy (Mod-2B). All the model parameters are given in Table 2. Simulations were performed using R software (3.3.3 version). 


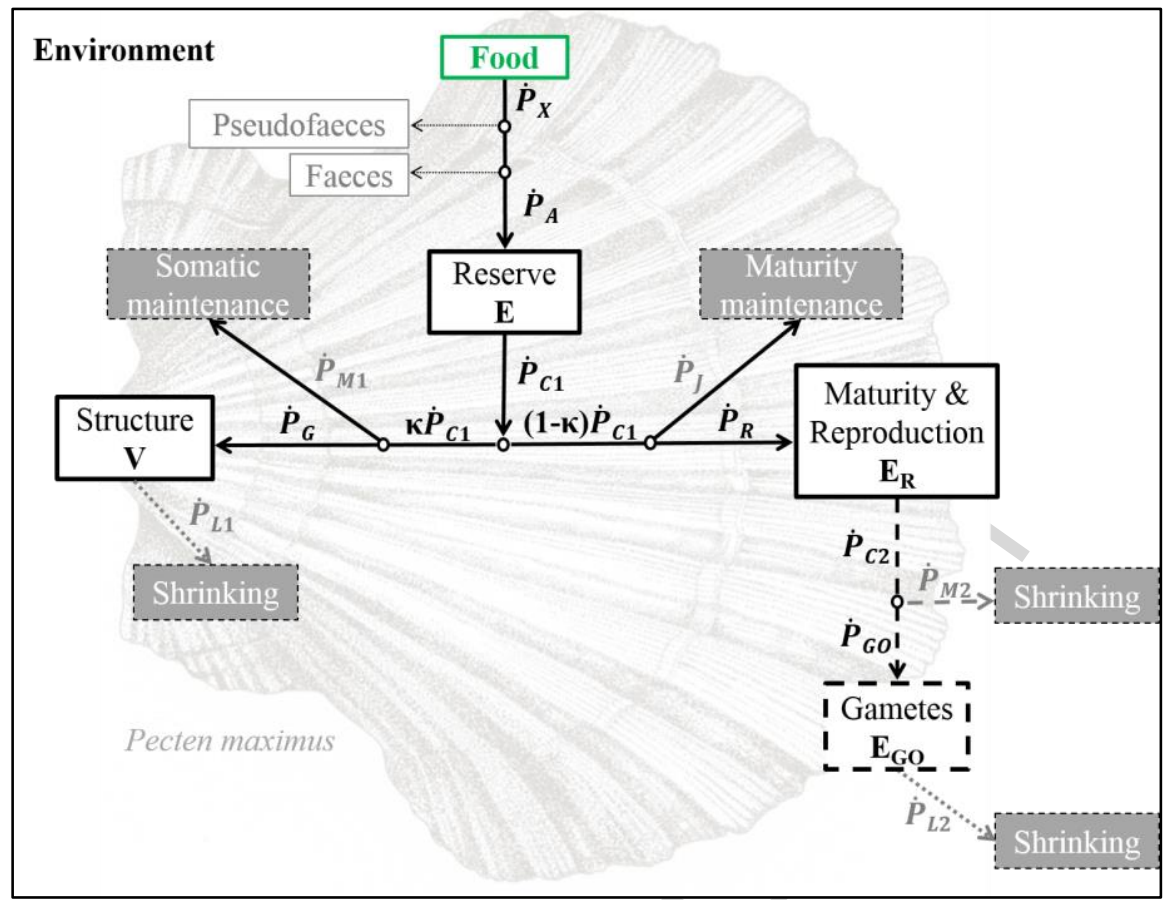

Figure 2: Schema of the P. maximus DEB model with four state variables adapted from Bernard et al. 2011 (Mod-2). Sources of energy to pay for somatic maintenance during prolonged starvation are indicated by grey dotted arrows. Modifications of the standard DEB model (3 state variables; Mod-1) are represented by dashed arrows for $\dot{P}_{C 2}, \dot{P}_{G O}, \dot{P}_{M 2}$ and $\dot{P}_{L 2}$.

Table 1: The three scallop DEB models tested in this study ( ${ }^{a}$ data only available for the Bay of Brest, ${ }^{b}$ data available for the Bay of Brest and Bay of Saint-Brieuc).

\begin{tabular}{|l|l|l|l|}
\hline & Mod-1 (Lavaud et al., 2014) & \multicolumn{1}{|c|}{ Mod-2A } & \multicolumn{1}{|c|}{ Mod-2B } \\
\hline State variables & V, E, E & V, E, E \\
\hline X-type food & $\mathrm{E}_{\mathrm{GO}}$ & V, E, E $\mathrm{E}_{\mathrm{R}}, \mathrm{E}_{\mathrm{GO}}$ \\
\hline Y-type food & Phytoplankton $^{\mathrm{b}}$ & Phytoplankton $^{\mathrm{b}}$ & $\begin{array}{l}\text { Phytoplankton }^{\mathrm{b}} \\
\text { Microphytobenthos }^{\mathrm{a}}\end{array}$ \\
\hline
\end{tabular}

\subsection{Model calibration}

The model was calibrated with field data observed over the 1998-2003 period in the Bay of Brest. recalibrated for this study. First, we set a new value for the ultimate shell length $\mathrm{L}_{\mathrm{w} \infty}$ (i.e., the maximum observed length reached in optimal condition i.e. $f=1$ ) at $20 \mathrm{~cm}$ instead of $12 \mathrm{~cm}$. Some field studies have shown that adult scallops can reach $16 \mathrm{~cm}$ in the most favourable conditions 
(Mason, 1957; Chauvaud et al., 2012), so we set $\mathrm{L}_{\infty}$ above this value. According to DEB theory, $L_{\infty}$ is calculated through the following equation:

$L_{w \infty}=f \frac{L_{m}}{\delta_{M}}=f \frac{\left(\frac{\kappa\left\{\dot{p}_{A m}\right\}}{\left[\dot{p}_{M}\right]}\right)}{\delta_{M}}$

where $\left\{\dot{p}_{A m}\right\}$ is the maximum surface specific assimilation, $\left[\dot{p}_{M}\right]$ is the volume-specific maintenance costs, $\kappa$ is the allocation fraction to growth and maintenance and $\delta_{M}$ is the shape coefficient. We modified the values of $\kappa,\left\{\dot{p}_{\mathrm{Am}}\right\}$ and $\left[\dot{p}_{\mathrm{M}}\right]$, while keeping $\delta_{M}=0.36$. We estimated the values of $\left\{\dot{p}_{\mathrm{Am}}\right\}$ from Strohmeier et al. (2009) and a known value of $\left[\dot{p}_{\mathrm{M}}\right]$ at the same reference temperature (Emmery, 2008). Therefore, we were able to recalculate $\kappa=0.38$.

To account for variability in the initial conditions between individuals, we simulated 20 individuals in each scenario (i.e., 20 different individual growth trajectories) by setting 20 different initial conditions of size and weight (i.e., first sampling of the year from EVECOS monitoring). Initial values for the four state variables $\left(\mathrm{E}, \mathrm{V}, \mathrm{E}_{\mathrm{R}}\right.$ and $\left.\mathrm{E}_{\mathrm{GO}}\right)$ were calculated using the equations given in Table 3 from the measurements obtained in the first sampling of the year. Individual growth simulations were then pooled together to compute average growth patterns and standard deviation.

Three parameters control spawning in our model: the gonado-somatic ratio GSI, photoperiod and phytoplankton concentration. Threshold values for each of these three parameters were set as follows: GSI $=15 \%$ (estimated according to biological data from EVECOS monitoring), photoperiod (Photo) $=$ 14 hours (spawning is possible only if the daylength is above $14 \mathrm{~h}$; Saout et al., 1999) and a phytoplankton concentration threshold (Phyto) $=2.5010^{5}$ cell L $^{-1}$ (average value corresponding to the beginning of a spring bloom; Paulet et al., 1997). In contrast to Lavaud et al. (2014), we calculated the GSI as the ratio between dry gonad mass and DFM, rather than as the ratio between wet gonad weight and cubic length. To assess the reproductive effort, individual DFM loss was estimated as the difference between individual DFM before and after spawning. Because spawning is mostly partial in P. maximus, $85 \%$ of the energy stored in $\mathrm{E}_{\mathrm{GO}}$ was released as gametes at spawning and the remaining $15 \%$ was kept in the buffer for a potential subsequent spawning if environmental conditions remained 
optimal until winter. If conditions deteriorated, energy stored in the reproduction buffer was then used

for the maintenance.

Field studies conducted in the Bay of Saint-Brieuc in the 1980s (e.g. Paulet et al., 1988) showed that phytoplankton blooms were much lower in this bay compared with the Bay of Brest. Over the 1998-2003 period, maximum phytoplankton concentrations in the Bay of Saint-Brieuc were always below the phytoplankton concentration threshold set for Bay of Brest. Therefore, we hypothesised that phytoplankton concentration might not be relevant for triggering spawning in this more oligotrophic bay. Consequently, we added a temperature criterion based on the findings of Fifas (2004), who observed a temperature threshold of $16^{\circ} \mathrm{C}$ for spawning in the Bay of Saint-Brieuc.

Table 2: List of the parameters implemented in the scallop DEB model. All rate parameters are given at $\mathrm{T}_{1}=15^{\circ} \mathrm{C}(=288.15 \mathrm{~K})$.

\begin{tabular}{|c|c|c|c|c|}
\hline Description & Symbol & Value & Units & Reference \\
\hline \multicolumn{5}{|l|}{ Biological parameters } \\
\hline Shape coefficient & $\delta_{M}$ & 0.36 & - & Lavaud et al. (2014) \\
\hline Length at puberty (reproductive maturity) & $L_{p}$ & 4 & $\mathrm{~cm}$ & Lavaud et al. (2014) \\
\hline \multicolumn{5}{|l|}{ Food assimilation } \\
\hline Radius of X-type particle & $r_{X}$ & 15 & $\mu \mathrm{m}$ & Lavaud et al. (2014) \\
\hline Radius of Y-type particle & $r_{Y}$ & 15 & $\mu \mathrm{m}$ & Lavaud et al. (2014) \\
\hline Yield of reserve on X-type particle & $y_{E X}$ & 0.7 & - & Lavaud et al. (2014) \\
\hline Yield of reserve on Y-type particle & $y_{E Y}$ & 0.4 & - & Lavaud et al. (2014) \\
\hline Max. specific filtration rate of X-type particle & $\dot{F}_{X m}$ & 6 & $\mathrm{~J} \mathrm{~d}^{-1} \mathrm{~cm}^{2}$ & this study \\
\hline Max. specific filtration rate of Y-type particle & $\dot{F}_{Y m}$ & 2 & $\mathrm{~J} \mathrm{~d}^{-1} \mathrm{~cm}^{2}$ & Lavaud et al. (2014) \\
\hline Mol.weight of X-type particle & $w_{X}$ & 26.95 & $\mathrm{~g} \mathrm{~mol}^{-1}$ & Lavaud et al. (2014) \\
\hline Mol.weight of Y-type particle & $w_{Y}$ & 25.4 & $\mathrm{~g} \mathrm{~mol}^{-1}$ & Lavaud et al. (2014) \\
\hline \multicolumn{5}{|l|}{ Reserve parameters } \\
\hline Volume-specific maintenance costs & {$\left[\dot{p}_{M}\right]$} & 24 & $\mathrm{~J} \mathrm{~cm}^{-3} \mathrm{~d}^{-1}$ & Emmery (2008) \\
\hline Energy conductance & $\dot{v}$ & 0.183 & $\mathrm{~cm} \mathrm{~d}^{-1}$ & Van der Veer (2006) \\
\hline Energy content of $1 \mathrm{~g}$ (dry weight) of reserve & $\rho_{E}$ & 19849 & $\mathrm{~J} \mathrm{~g}^{-1}$ & Lavaud et al. (2014) \\
\hline Molecular weight of reserve & $w_{E}$ & 23.9 & $\mathrm{~g} \mathrm{~mol}^{-1}$ & Lavaud et al. (2014) \\
\hline \multicolumn{5}{|l|}{ Structure parameters } \\
\hline Volume specific cost of growth & {$\left[E_{G}\right]$} & 2959 & $\mathrm{~J} \mathrm{~cm}^{-3}$ & Lavaud et al. (2014) \\
\hline Allocation fraction to growth and maintenance & $\kappa$ & 0.38 & - & this study \\
\hline Density of structure & $d_{V}$ & 0.12 & $\mathrm{~g} \mathrm{~cm}^{-3}$ & Lavaud et al. (2014) \\
\hline Energy content of $1 \mathrm{~g}$ (dry weight) of structure & $\rho_{V}$ & 19849 & $\mathrm{~J} \mathrm{~g}^{-1}$ & Lavaud et al. (2014) \\
\hline Yield of structure tissue used for maintenance & $Y_{L 1}$ & 1 & - & Bernard et al. (2011) \\
\hline \multicolumn{5}{|l|}{ Reproduction parameters } \\
\hline Reproduction efficiency & $\kappa_{G o}$ & 0.70 & - & this study \\
\hline Density of gonad & $d_{G o}$ & 0.276 & $\mathrm{~g} \mathrm{~cm}^{-3}$ & this study \\
\hline Yield of gonad tissue used for maintenance & $Y_{L 2}$ & 1 & - & Bernard et al. (2011) \\
\hline Energy content of $1 \mathrm{~g}$ of gonad & $\rho_{G o}$ & 21630 & $\mathrm{~J} \mathrm{~g}^{-1}$ & Bernard et al. (2011) \\
\hline
\end{tabular}


Temperature threshold for spawning

Gonado-somatic index threshold for spawning
${ }^{\circ} \mathrm{C}$

$-$

$\mathrm{K}$

Lavaud et al. (2014)

K Lavaud et al. (2014)

Table 3: Initial state variables of the scallop DEB model. Values vary for each of the 20 individuals simulated, according to their initial length and initial dry flesh mass.

\begin{tabular}{lccc}
\hline \multicolumn{1}{c}{ Initial conditions } & Symbol & Equation & Units \\
\hline Initial length & $L_{0}$ & Observed measurements in the first & $\mathrm{cm}$ \\
Initial dry flesh mass & $W_{d 0}$ & sampling of the year & $\mathrm{g}$ \\
\hline Initial structure & $V_{0}$ & $=\left(\delta_{M} L_{0}\right)^{3}$ & $\mathrm{~cm}^{3}$ \\
Initial reserve & $E_{0}\left[E_{m}\right] V_{0}$ & $\mathrm{~J}$ \\
Initial gametes & $E_{G O 0}$ & $=\frac{\left(W_{d 0} \times \rho_{G O}\right)}{\kappa_{G O}}$ & $\mathrm{~J}$ \\
Initial reproduction & $E_{R 0}$ & $=\rho_{E}\left(W_{d 0}-V_{0} d_{V}\right)-E_{0}-E_{G O 0}$ & $\mathrm{~J}$ \\
\hline
\end{tabular}

\subsection{Environmental forcing}

\subsubsection{Field data}

The environmental variables used as forcing variables in the model are presented in Fig. 3. Three

food proxies considered as the main food sources for scallops (e.g. Lorrain et al., 2002; Marchais, 2014) were monitored for our model in the Lanvéoc area (Fig. 1.): particulate organic matter (POM, expressed initially in $\mathrm{mg} . \mathrm{L}^{-1}$ but transformed a posteriori to particles $\mathrm{L}^{-1}$ ), phytoplankton concentration (in cell $\mathrm{L}^{-1}$ ) and microphytobenthos concentration (also converted to cell $\mathrm{L}^{-1}$ ). Microphytobenthos concentration was provided by the IUEM (Institut Universitaire Européen de la Mer) observatory (Leynaert, pers. comm.). As microphytobenthos concentration was not available for the studied period (1998-2003), we used a mean annual microphytobenthos profile that we applied for each year from 1998 to 2003 (Fig. 3b). POM data (in $\mathrm{mg} \mathrm{L}^{-1}$ ) were transformed into the number of particles per litre considering each particle to have an average diameter of $30 \mu \mathrm{m}$ (weight $=1.410^{-5} \mathrm{~g}$; density =1) (Lavaud et al. 2014). 
Weekly bottom temperatures were measured at Sainte-Anne from 1998 until 2003 by the SOMLIT monitoring network (Fig. 3a). Phytoplankton data and surface seawater temperature in the Bay of Saint-Brieuc from 1998 to 2003 were available from the REPHY monitoring network (Fig. 3c). All these environmental measurements were linearly interpolated to fit the daily time step of the simulations.

a)

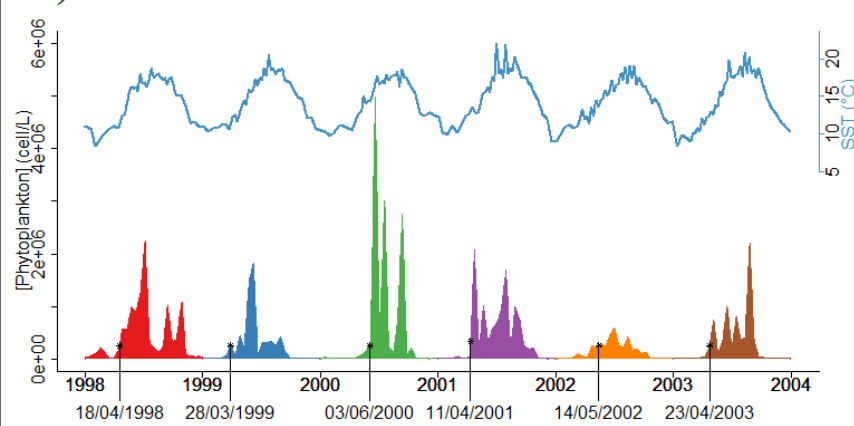

b)

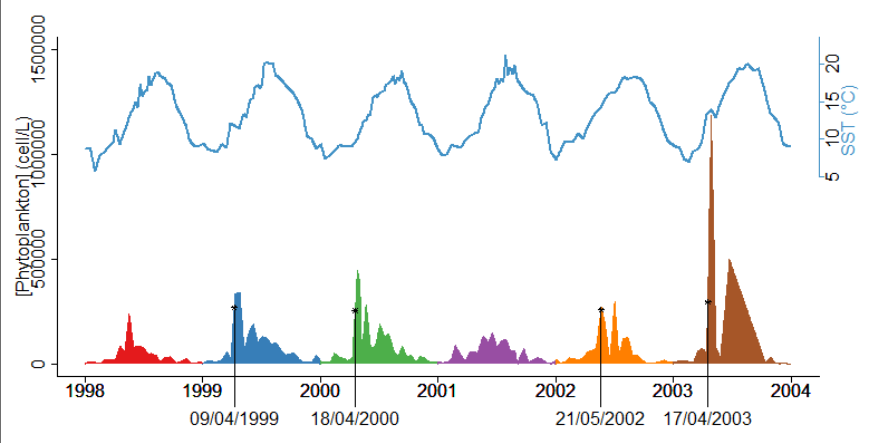

c)

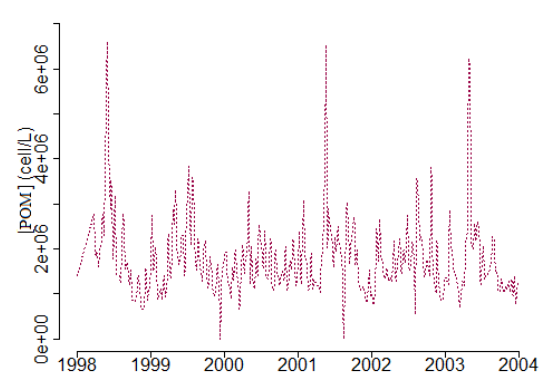

d)

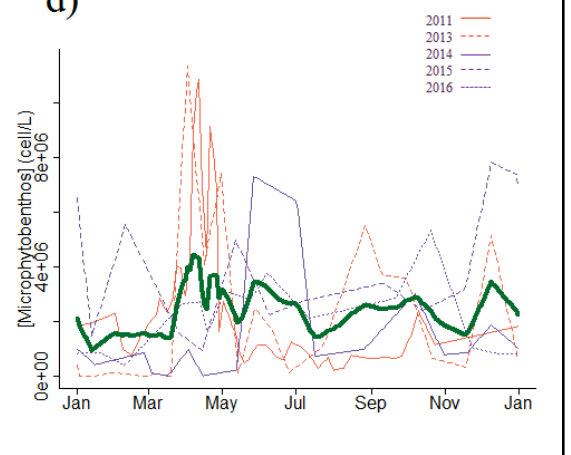

Figure 3: Environmental forcing from 1998 to 2003 in (a,c,d) the Bay of Brest (Lanvéoc station) and (b) Bay of Saint-Brieuc (Saint-Pol station) used for the DEB model simulations. (a,b)

phytoplankton concentration (one colour per year; cell/L) and seawater surface temperature (SST, light blue line; $\left.{ }^{\circ} \mathrm{C}\right)$. The dates on $\mathrm{x}$-axis indicate the time, each year, when the phytoplankton concentration threshold for spawning was reached $\left(2.5010^{5}\right.$ cell/L). (c) Particulate Organic Matter concentration

(POM, magenta line; cell/L) measured in the Bay of Brest. (d) Microphytobenthos concentration measured in 2011 and from 2013 to 2016 in the Bay of Brest. Mean microphytobenthos concentration is shown by a green line. 
In order to study the potential effect of climate change on the reproductive cycle of $P$. maximus, we used monthly time series of predicted atmospheric temperature $\left(\mathrm{T}_{\mathrm{Atm}}\right)$ from the RCP2.6 (i.e., an increase of 0.3 to $1.7^{\circ} \mathrm{C}$ ) and RCP 8.5 scenarios (a drastic increase of 2.6 to $4.8^{\circ} \mathrm{C}$ ) from 2040 to 2100 (IPCC Representative Concentration Pathways, Appendix A). For each scenario, we converted $\mathrm{T}_{\mathrm{Atm}}$ into SST by using linear regressions according to the following equation:

$\mathrm{SST}=a \times \mathrm{T}_{A t m}+b$

where $a$ is a coefficient that estimates the determination coefficient, $b$ is a coefficient that represents the intercept (Fig. 4). To the best of our knowledge, no phytoplankton models or projections are currently available for our sites. Therefore, we used the previously recorded time series of phytoplankton, POM and microphytobenthos in the Bay of Brest from 1988 to 2003 (see previous paragraph) as potential conditions in future scenarios (letters $\mathrm{A}$ to $\mathrm{F}$ were used to refer to the phytoplankton concentrations observed from 1998 to 2003, respectively). RCP8.5 scenarios. In each case, $6 \times 20=120$ individual trajectories were simulated, with initial conditions corresponding to initial L and DFM of a representative set of individuals sampled during the 6-year monitoring program (see Scallop data in the results section).

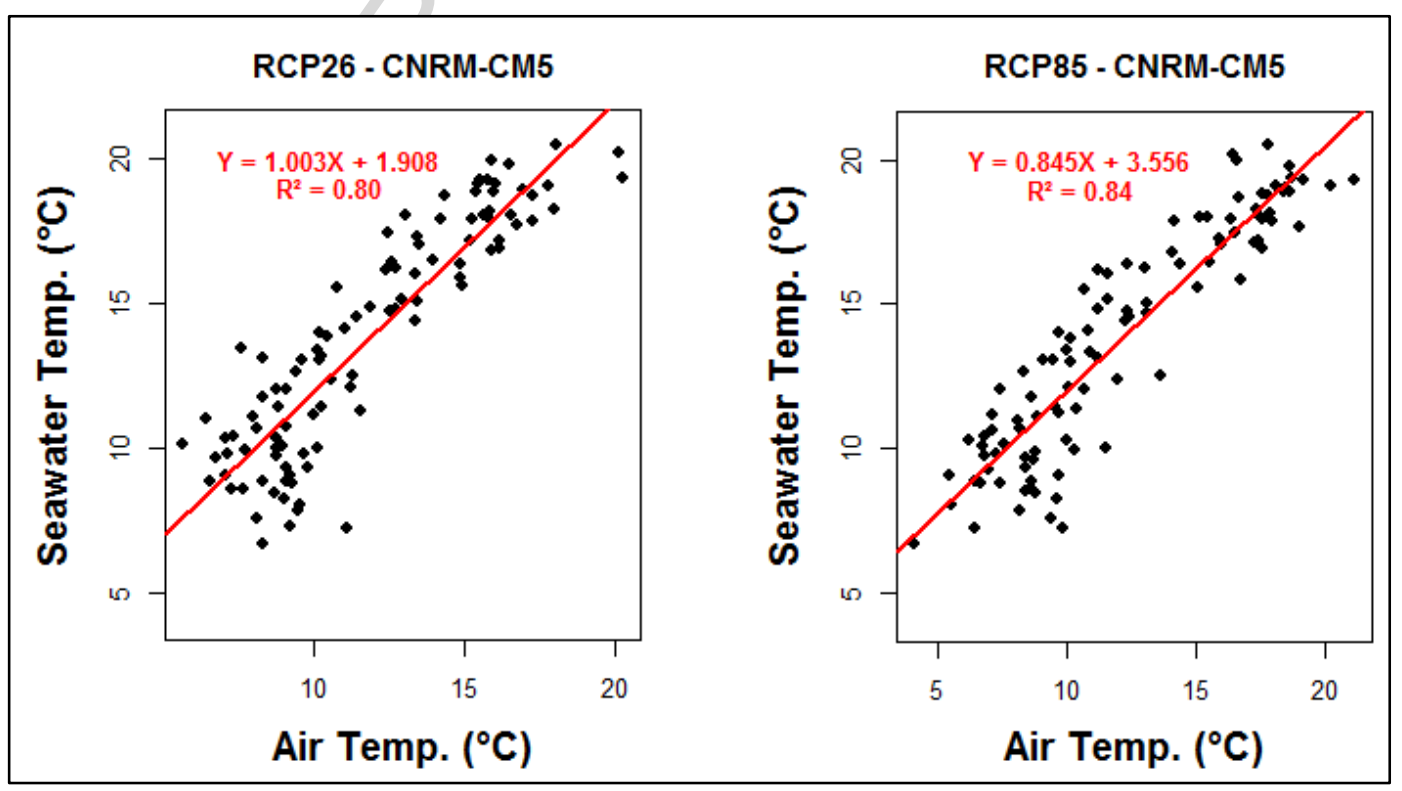


Fig 4: Relations between monthly air temperature from the RCP scenarios and monthly seawater temperature in the Bay of Brest (from 2006 to 2014): on the left, monthly air temperatures on monthly seawater temperature under the RCP2.6 scenario with the CNRM-CM5 model; on the right, monthly air temperatures on monthly seawater temperature under the RCP8.5 scenario with the CNRM-CM5 model.

\subsection{Statistical analysis}

To evaluate the best fit, mean simulations for each model (Mod-1, Mod-2A and Mod-2B) and mean observed data were compared using a Taylor diagram. This diagram provides a statistical summary of the agreement between a reference (observed data) and modelling results (Taylor, 2001). Three statistical measures are presented in the Taylor diagram: the centred root mean square (RMS) difference, normalized standard deviation, and Pearson's correlation coefficient. All statistical analyses were conducted in R version 3.3.3 (R Core Team, 2017). 


\section{Results}

297

298

299

300

301

302

303

304

305

306

307

308

309

310

311

312

313

314

315

\subsection{Contrasted environmental forcing conditions in the two study sites}

Between 1998 and 2003, sea surface temperatures (SST) in the Bay of Brest reached a minimum of $8.3^{\circ} \mathrm{C}$ in February 1998 and a maximum of $22.1^{\circ} \mathrm{C}$ in July 2001 (Fig 3a). The overall annual mean was $14.0 \pm 0.3^{\circ} \mathrm{C}$. The warmest year was 2001 , with a yearly mean temperature of $14.5^{\circ} \mathrm{C}$. This year also had the warmest summer, with a mean temperature of $18.4^{\circ} \mathrm{C}$. The coldest year was 1998 , with a yearly mean temperature of $13.7^{\circ} \mathrm{C}$. The coldest summer was 2000 , with a mean temperature of 16.9 $9^{\circ}$. Phytoplankton concentration from 1998 to 2003 averaged 328,000 cell/L per year, with an intra-annual SD of 135,000 cell/L. Phytoplankton concentration showed a seasonal pattern, with maximum values in spring and summer and minimum values in winter (Fig 3a). The magnitude and timing of spring and summer blooms showed high inter-annual variability. For example, the spring bloom reached $5,000,000 \mathrm{cell} / \mathrm{L}$ in 2000 , but the maximum phytoplankton concentration recorded in 2002 was 600,000 cell/L. The bloom onset date also differed among years. The first bloom observed in $2000(30,000$ cell/L) occurred on 20 January, while it was observed on 25 February in 1998 (206,000 cell/L).

The POM concentration showed similar patterns over the study period (Fig. 3a). However, larger peaks were observed in 1998, 2001 and 2003, at about 6,460,000 particles $\mathrm{L}^{-1}$, compared with lower values of 3,640,000 particles $\mathrm{L}^{-1}$ in 1999, 2000 and 2002.

Microphytobenthos concentration showed two seasonal trends (Fig. 3b). The first pattern was observed in 2011 and 2013 with a large peak in spring and two smaller peaks in autumn and winter. The second pattern, observed in 2014, 2015, and 2016, showed a peak in early summer and two smaller ones in autumn and winter. The smallest number of microphytobenthic species $(n=22)$ were identified in 2011 and a maximum of 67 species were identified in 2016. For the rest of the study, we used a mean profile of microphytobenthos computed by taking the average of all these observations (Fig. 3d). 
In the Bay of Saint-Brieuc, SST fluctuated between a minimum of $5.8^{\circ} \mathrm{C}$ in February 1998 and a maximum of $21.2^{\circ} \mathrm{C}$ in July 2001 (Fig. 3b), thus showing a greater range of variation than the Bay of Brest. The average SST was $12.6 \pm 0.5^{\circ} \mathrm{C}$. The warmest year was 2003 with a mean temperature of $13.6^{\circ} \mathrm{C}$. This year also had the warmest summer with a mean temperature of $18.4^{\circ} \mathrm{C}$. As in the Bay of Brest, the coldest year was 1998 , with a mean temperature of $12.6^{\circ} \mathrm{C}$, and 2000 was the coldest summer, with a mean temperature of $16.5^{\circ} \mathrm{C}$.

Phytoplankton concentrations were maximal in spring and summer and minimal in winter (Fig 3b). The annual phytoplankton concentration from 1998 to 2003 averaged 40,764 $\pm 4,990$ cell $\mathrm{L}^{-1}$. Bloom intensities were lower than in the Bay of Brest, but the magnitude and timing appeared quite different from year to year. For example, the 2003 spring bloom peaked at 1,187,000 cell $\mathrm{L}^{-1}$, while only reaching 150,000 cell L $\mathrm{L}^{-1}$ in 2001. The earliest first bloom was observed in 1999, on April 1 (114,000 cell $\left.\mathrm{L}^{-1}\right)$, while the latest was observed in 2001, on May $14\left(103,000\right.$ cell $\left.\mathrm{L}^{-1}\right)$.

\subsection{Comparing the DEB models}

Simulations of dry flesh mass using model Mod-2A fitted the observations better than simulations from Mod-1 (Fig. 5). The addition of the fourth state variable $\mathrm{E}_{\mathrm{Go}}$ seemed to improve prediction of spawning events. Spawning events can be identified on each curve by a sharp decline in DFM. The spawning period was more pronounced using Mod-2A than with Mod-1. For example, under Mod-1, the first spawning occurred on May 11 in 1999 whereas it appeared March 28 under Mod-2A. However, neither model successfully reproduced the observed increase in DFM from March to May. On average, the difference between observed and simulated DFM values from January to May was \pm $0.39 \mathrm{~g}$ under Mod-1 and $\pm 0.95 \mathrm{~g}$ under Mod-2A. DFM modelled using Mod-2B was more accurate and the increase of DFM in spring fitted the observed data well $( \pm 0.09 \mathrm{~g}$ of difference). Similarly to Mod-2A, the spawning period was longer and more realistic than when using Mod-1. The addition of microphytobenthos to phytoplankton for P. maximus food intake allowed a better simulation of growth and reproductive activity, especially in the spring. For all years, model Mod-2B gave the best fit between observations and simulations of growth, with a mean correlation coefficient up to 0.9 and a 


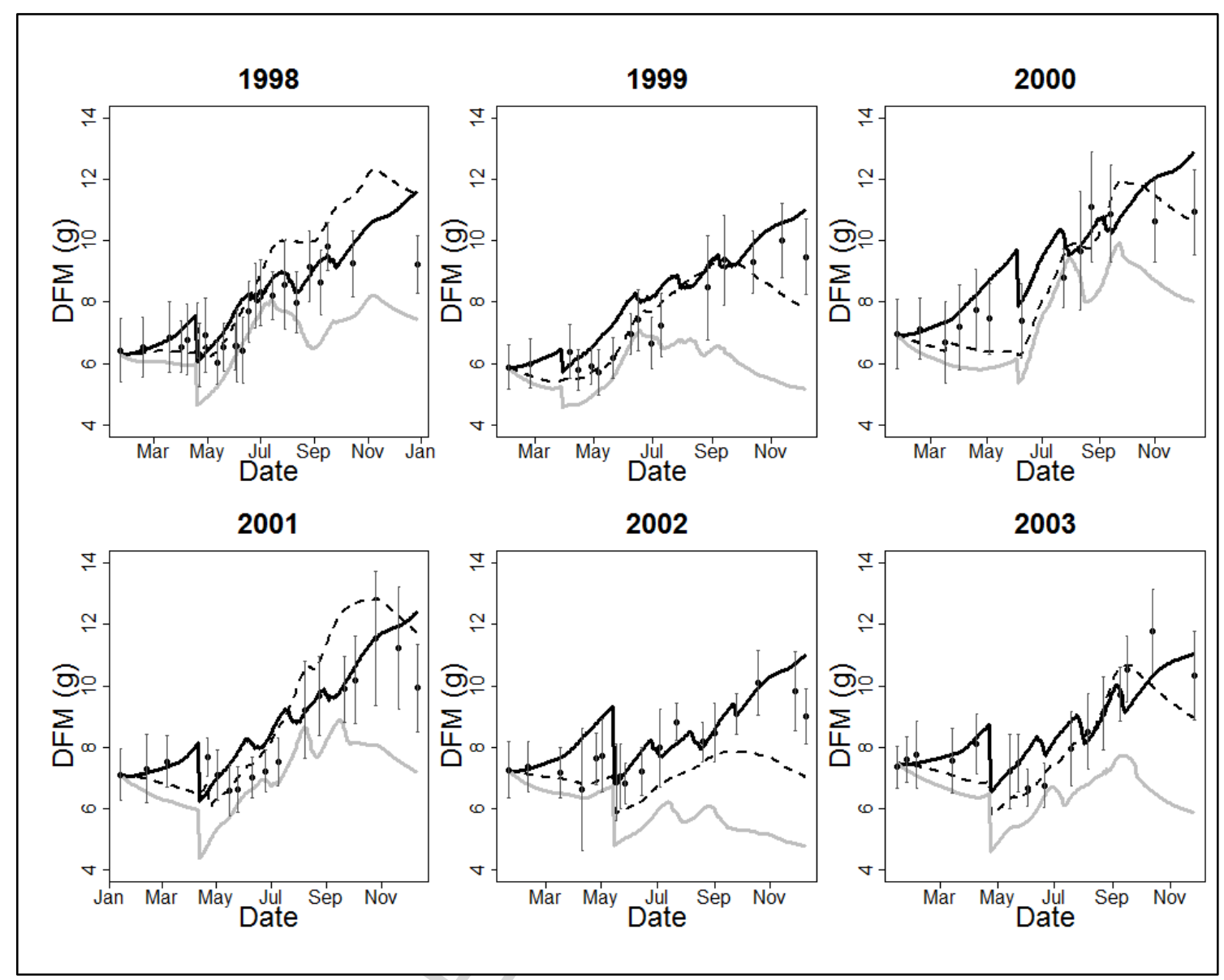

Figure 5: Mean observed $( \pm \mathrm{SD}, \mathrm{N}=20$, black dots) and simulated $(\mathrm{N}=20)$ dry flesh mass $(\mathrm{DFM})$ of 3-year-old scallops in the Bay of Brest between 1998 and 2003, using Mod-1 (dotted black line), 


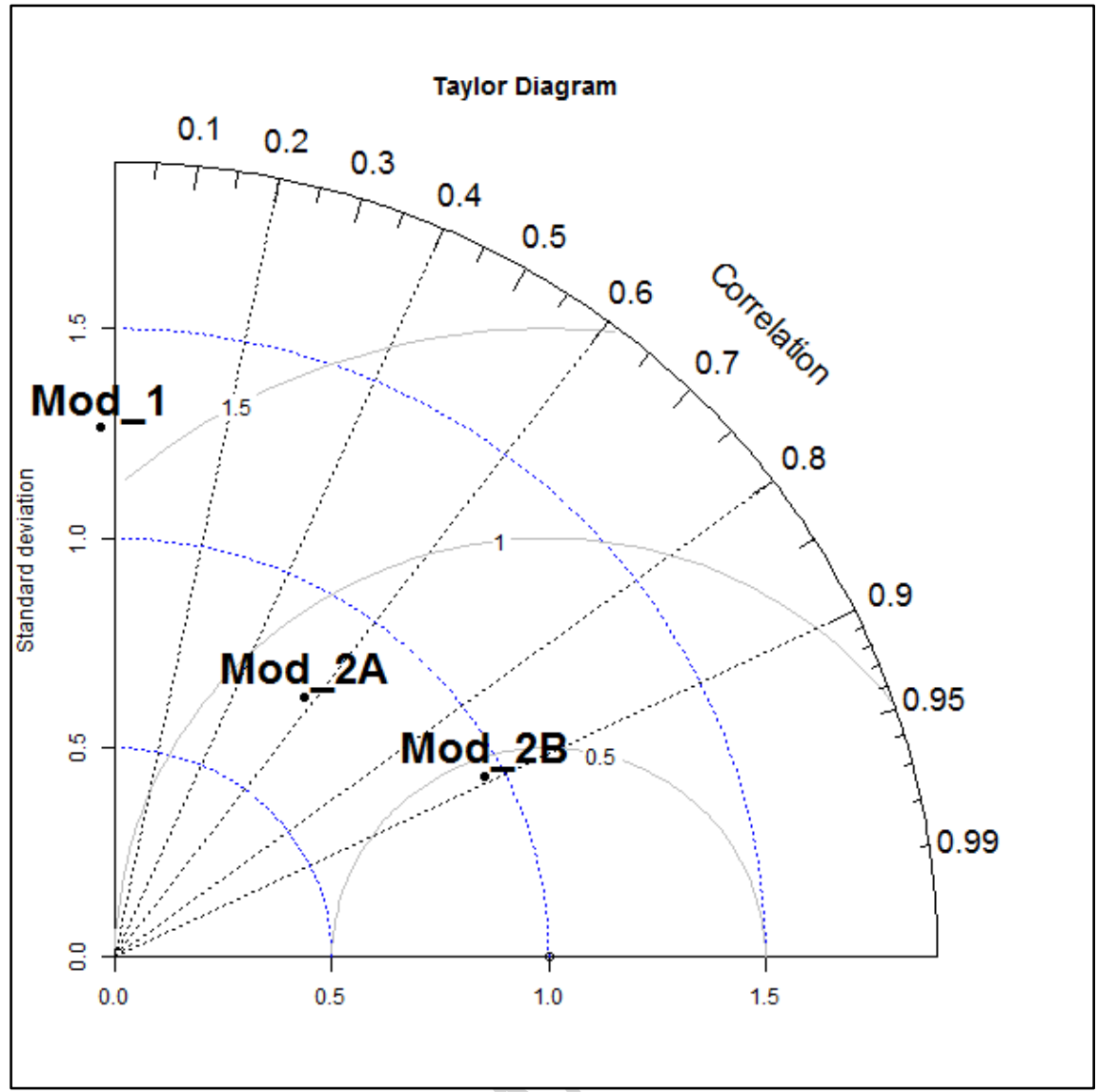

Figure 6: Taylor diagram presenting the normalized standard deviation, Pearson's correlation coefficient and centred root mean squared difference (grey line) between simulated and observed dry flesh mass. The average of the 6 years simulated with each model is shown by a black dot.

\subsection{Simulation of reproductive activity}

Simulations of individual DFM using Mod-2B in the two study areas highlighted three major trends in scallop reproductive activity. Firstly, the number of spawning events per reproductive season varies between years (Fig. 7). At least four spawning events were simulated for almost all individuals in the Bay of Brest except in 2000, when there were only three major spawning events. This could be because the phytoplankton threshold for spawning was only reached in June this year and the summer seawater temperatures were colder (Fig. 3).

Secondly, the spawning period lasted from early spring to early autumn, corresponding to a wide period of 4 to 6 months depending on the year. This temporal window was shorter in 2000 and 2002 (around 100 days) compared with 1998 and 1999 (above 150 days; Fig. 7). The interval between 
spawning events (i.e. time for gametogenesis) ranged from 25 to 50 days. In the literature, spawning in P. maximus in the Bay of Brest was reported to span over a 6-month period with intervals of 20 to 50 days (Paulet et al., 1995). Our simulations are in full agreement with these field observations, showing the ability of the model to accurately simulate energy allocation to reproduction and spawning events in P. maximus.

The third observed pattern was asynchronicity between individuals, observed every year following the first synchronous spawning (except in 1999 when asynchronicity was also observed for the first spawning event). For instance, in 2003 spawning occurred in all individuals within 8 days while in 1999 it took 29 and 26 days for all the individuals to spawn during the first and fourth spawning events, respectively.

In comparison with results obtained for the Bay of Brest, only two clear spawning events were observed in the Bay of Saint-Brieuc (Fig. 8). Furthermore, in 2000, only 22\% of individuals spawned twice. The spawning period was much shorter ( $\sim 50$ days $)$ and only occurred in summer. The first spawning event was mainly synchronous between individuals, except in 1999. In contrast, the second spawning event was mainly asynchronous but the temporal window did not exceed 15 days. 


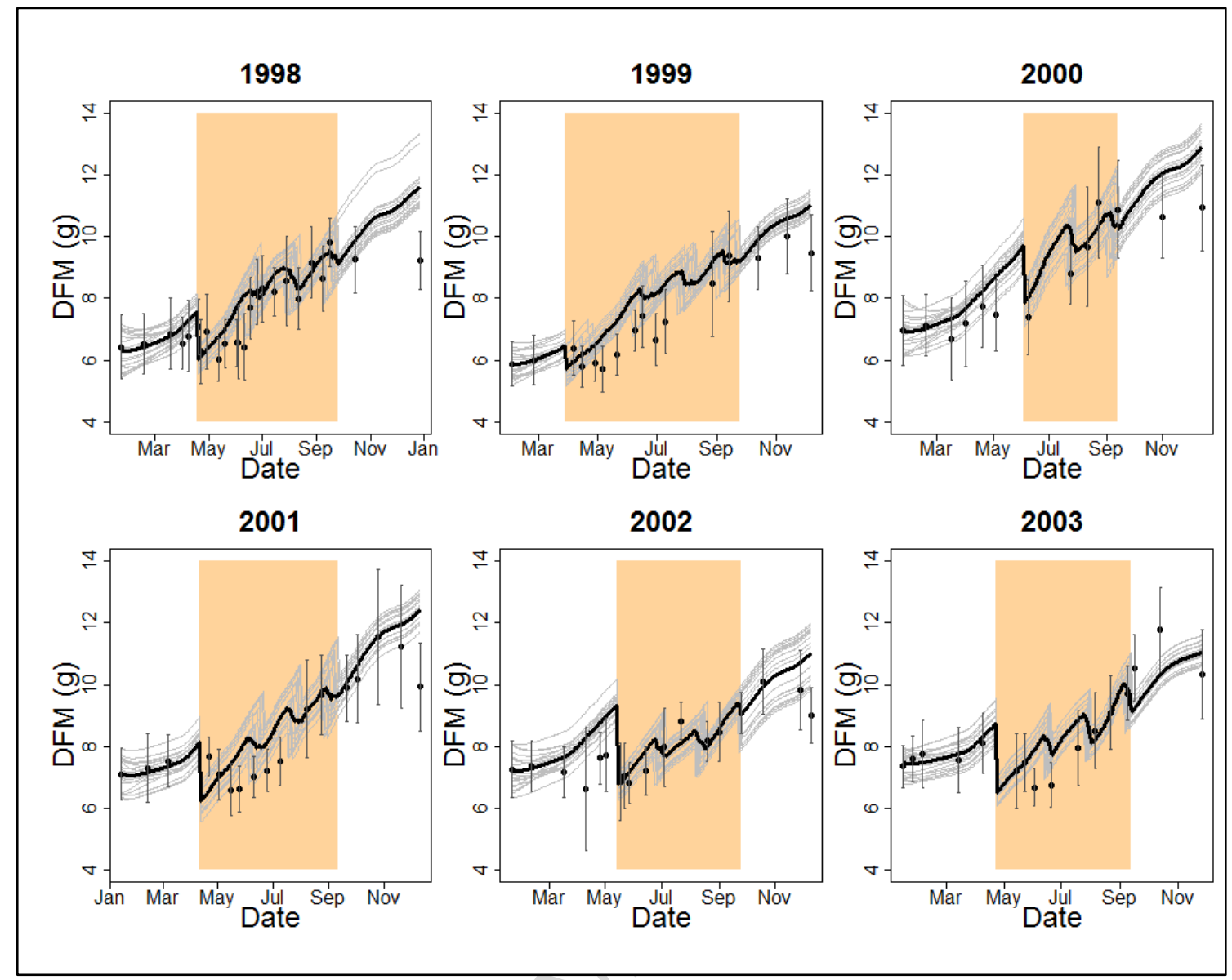

Figure 7: Mean observed $( \pm S D, N=20$, black dots $)$ and simulated $(N=20$, thick black line $)$ dry 


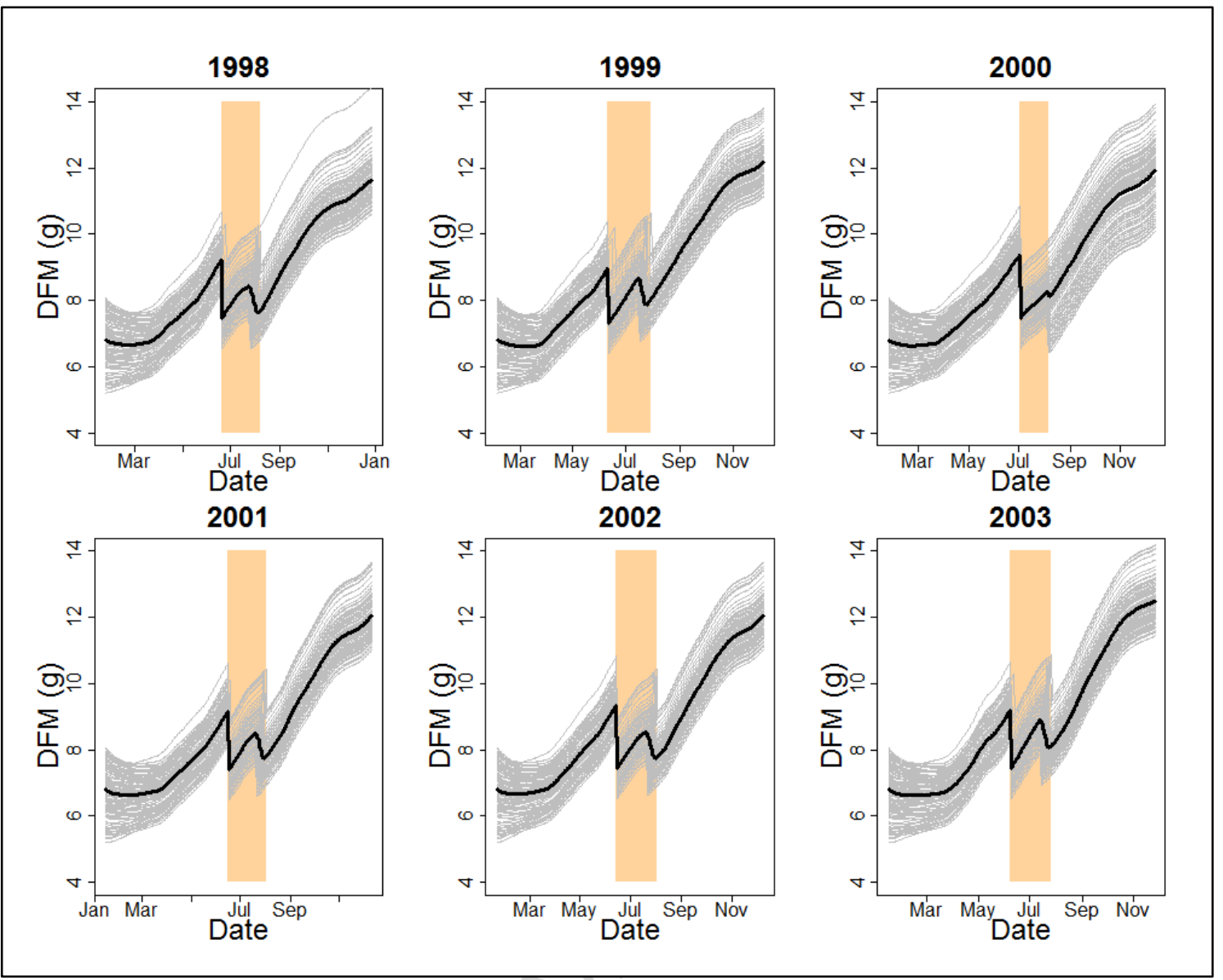

Figure 8: Individual (grey lines) and mean simulated ( $\mathrm{N}=120$, thick black line) dry flesh mass (DFM) of 3-year-old scallops in the Bay of Saint-Brieuc in 1998-2003 using Mod-2B. The orange area shows the spawning period.

\subsection{Simulating reproductive activity of $P$. maximus in a warming ocean}

In order to evaluate the impacts of climate change on the reproduction of $P$. maximus off the coast of Brittany, we simulated DFM in two extreme cases: the RCP2.6 scenario (an increase of 0.3 to $1.7^{\circ} \mathrm{C}$ ) and the RCP8.5 scenario (a drastic increase of 2.6 to $4.8^{\circ} \mathrm{C}$ ) and six phytoplankton conditions (scenarios A to F).

In the Bay of Brest, under the RCP2.6 scenario, spawning dates were similar to current observations and no change in the individual spawning strategies were observed (Fig. 9a-b). Under the RCP8.5 scenario, we observed a decrease of the interval between spawning events after the first one except with phytoplankton regime D during the third spawning event (Fig. 9a-c). The second and third spawnings occurred 5 and 10 days earlier, respectively, under phytoplankton regimes $\mathrm{C}$ and $\mathrm{E}$, and the 
fourth spawning occurred 20 days earlier under phytoplankton regimes B, D and F. Finally, more spawning occurred in autumn with a higher number of individuals spawning four to five times.

Spawning events were less frequent in the Bay of Saint-Brieuc than in the Bay of Brest in both temperature scenarios. Under the RCP2.6 scenario, two spawning events were observed as in the simulation of the current situation (Fig. 9d-e). In contrast, under RCP8.5 scenario, a third spawning event appeared every year (Fig. 9f). Moreover, spawning occurred 30 to 48 days earlier depending on the phytoplankton scenario. The spawning period was slightly shorter under the RCP2.6 scenario (around 40 days), while it was longer under the RCP8.5 scenario, reaching 80 days. Furthermore, asynchronicity between individuals was only observed under the RCP8.5 scenario, especially during the second spawning event.

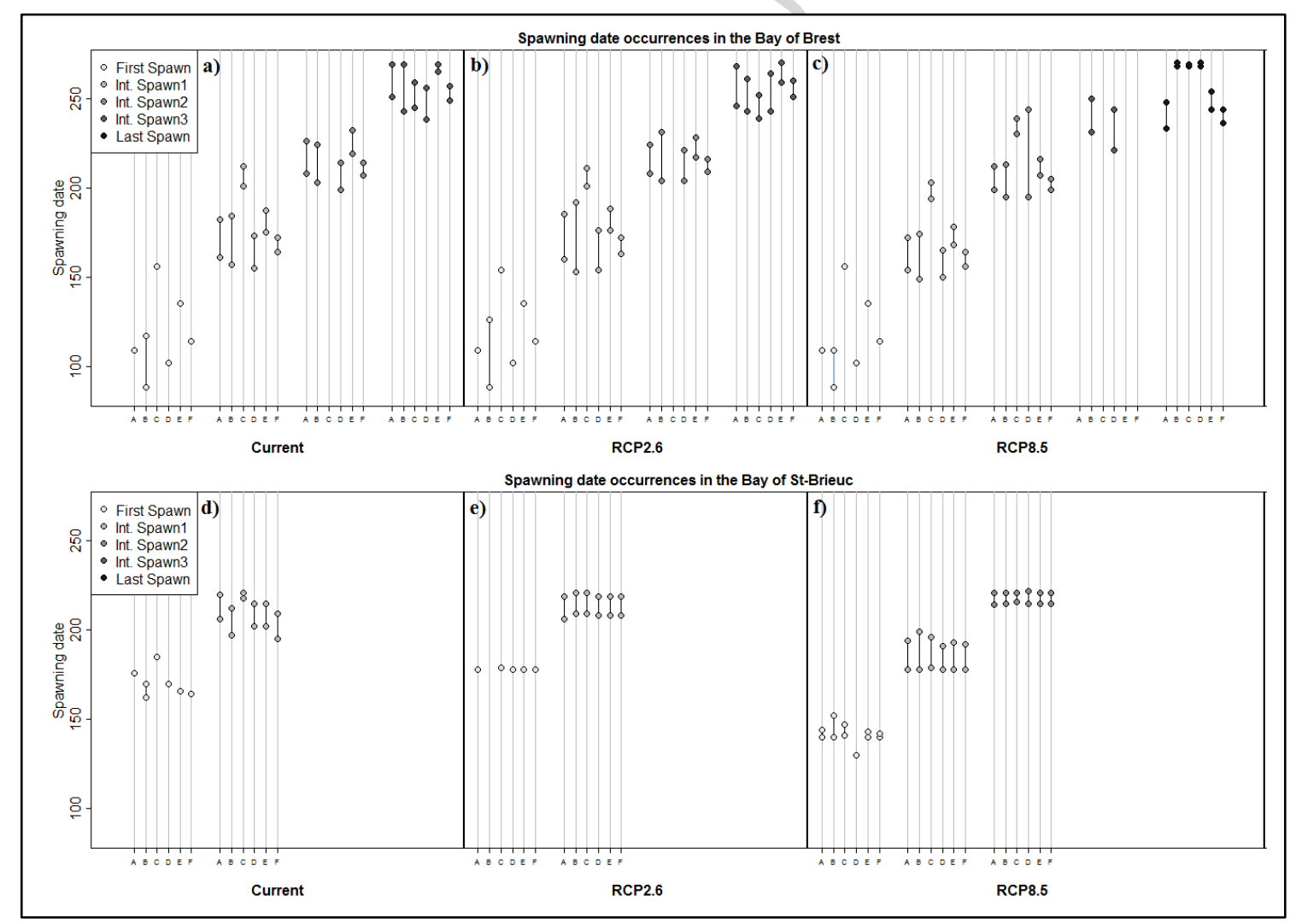

Figure 9: Simulated spawning date (Int. = Intermediate) in the Bay of Brest (a to c) and Bay of Saint-Brieuc (d to f) under three temperature scenarios (current, RCP2.6 and RCP8.5) and six phytoplankton regimes (A to F, corresponding to conditions in years 1998 to 2003). The lines between 

spring phytoplankton concentrations on one hand and summer SST (mean value) on the other (Fig. 10). The date of the first spawning event was significantly inversely correlated with summer SST in the Bay of Saint-Brieuc (Fig. 10, linear regression: $\mathrm{r}^{2}=0.70, p<0.05$, slope $=-11 \mathrm{~d}^{\circ} \mathrm{C}^{-1}$ ). In the Bay of Brest, the date of the first spawning event was significantly inversely correlated with the spring phytoplankton bloom concentration (Fig. 10, linear regression: $\mathrm{r}^{2}=0.74, p<0.05$, slope $=-1.2210^{-4} \mathrm{~d}$ cell $\left.\mathrm{L}^{-1}\right)$.

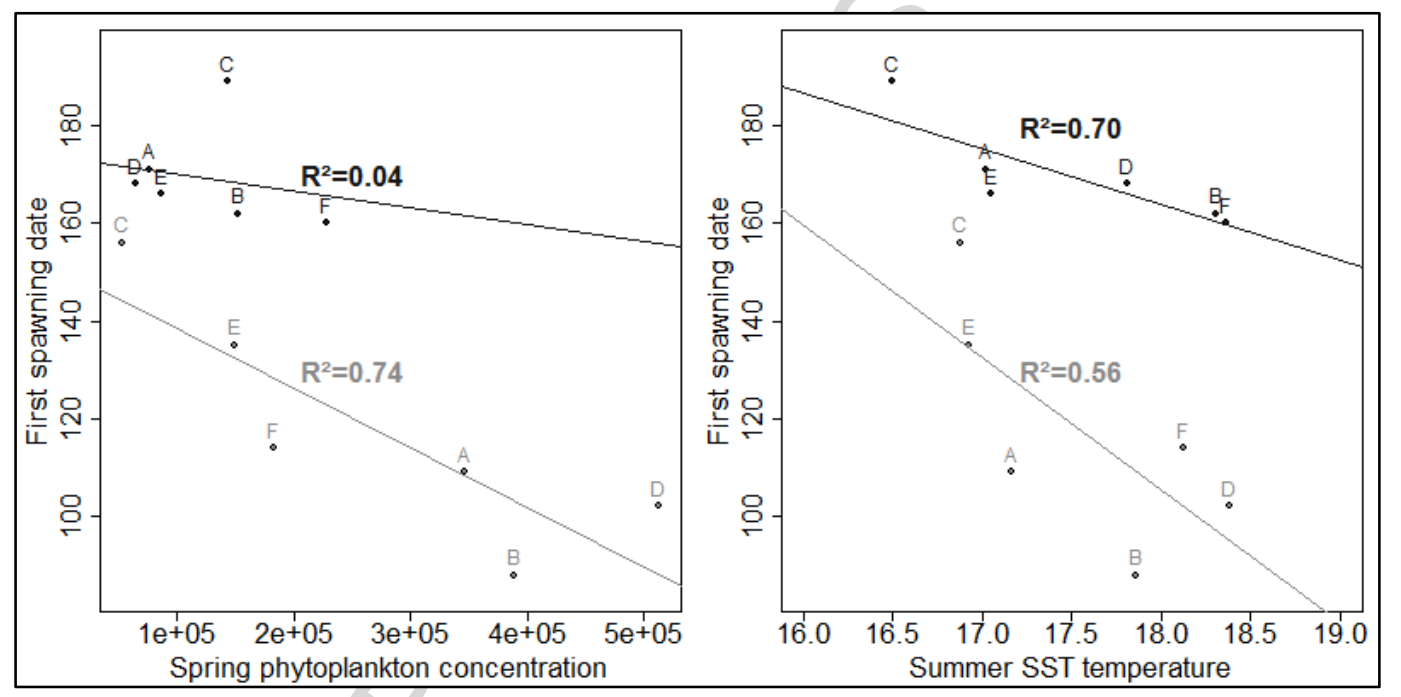

Figure 10: Relationships between environmental conditions (left: spring phytoplankton concentration; right: summer SST temperature) and the first spawning date in the Bay of Brest (grey) and in Bay of Saint-Brieuc (black) for the six phytoplankton regimes (A to F). 


\section{Discussion}

The main objective of this study was to quantify the influence of environmental variables (temperature and food sources) on the reproductive processes of the great scallop, P. maximus, and explore the potential impacts of climate change on its dynamics. We improved an existing scallop DEB model developed by Lavaud et al. (2014) by detailing the reproductive processes and by adding microphytobenthos as a new food source.

In order to improve the DEB model for P. maximus, a fourth state variable was added to describe the fixation of energy in gametes, as done by Bernard et al. (2011) for the Pacific oyster, Crassostrea gigas. Furthermore, the maximum possible shell length was assumed to be $20 \mathrm{~cm}$ rather than the previous assumption of $12 \mathrm{~cm}$, since studies have shown that adult scallops can reach $16 \mathrm{~cm}$ in the most favourable conditions (Mason, 1957; Chauvaud et al., 2012) and thus the ultimate length would presumably be above $16 \mathrm{~cm}$. This led to the recalculation of three model parameters: $\left\{\dot{p}_{A m}\right\},\left[\dot{p}_{M}\right]$ and $\kappa$. The new values obtained are different from the previous version in Lavaud et al. (2014), particularly $\kappa$. The previous value, fixed at 0.86 , was high compared with other bivalve species. For instance, the $\kappa$ value for Crassostrea gigas is around 0.45 . Considering that, in some environments, $P$. maximus could spawn more than three times within the same reproductive season and that its gonad represents more than $30 \%$ of the whole flesh weight at maturity, it seems logical that this species would have a high energy allocation ratio (and thus a low value for $\kappa$ ) similarly to $C$. gigas. Considering this, the new value calculated here is probably more consistent with the reproductive capacity of $P$. maximus. These changes do not fundamentally alter the dynamics of the model, but allow more spawning events and higher fecundity than other versions of the model. Of course, further testing in other locations with contrasted forcing conditions as well as with younger age-classes would also be needed to fully validate this updated version of the scallop DEB model.

Another improvement made in the current model concerns trophic resources. Microphytobenthos was added as a new source of food for scallops. Previously, Lavaud et al. (2014) demonstrated that POM constitutes an additional food source allowing scallops to compensate phytoplankton limitation. In addition, our study suggests that microphytobenthos would probably also be a valuable source of 
food that could sustain energy acquisition, especially in spring. For the moment, the taxonomic composition of each food source is not detailed in the model, but several studies have shown relationships between specific phytoplankton species and life history traits of the great scallop in Brittany. For example, Chauvaud et al. $(1998,2001)$ showed, in the Bay of Brest, that growth and food intake of $P$. maximus were dependent on phytoplankton taxonomic composition and concentration. The related growth cessation depended on massive sedimentation of diatom blooms or toxic dinoflagellate blooms. For example, $P$. maximus food intake and growth were highest when

Cerataulina pelagica blooms occurred and lowest during Gymnodinium nagasakiense blooms. In addition, Lorrain et al. (2000) demonstrated that large bottom concentrations of chlorophyll- $a$, following diatom blooms, could have a negative effect on the ingestion or respiration of $P$. maximus juveniles, either by gill clogging or by oxygen depletion at the water-sediment interface associated with the degradation of organic matter. The current version of the DEB model does not take into account these specific effects which are linked to the type of food that is available. However the current model provides the basis for taking them into consideration in future studies.

One major difficulty with a modelling approach is to obtain a sufficient dataset to calibrate, test and validate a numerical model. When using a bioenergetics model, this implies monitoring growth and reproduction of marine organisms and their surrounding environmental data, at the same place and ideally over a long period (many years) to evaluate temporal phenotypic variability. In our study, the Bay of Brest sampling sites (St Anne, Roscanvel, Lanvéoc) are not closed off from each other but are instead located in a very well mixed area within the Bay of Brest (Salomon and Breton, 1991) where scallops are the most abundant. So we can suppose that environmental data are sufficiently representative of conditions encountered by scallops. In the Bay of Saint Brieuc, there is no growth monitoring of scallops and there are too many gaps in the environmental data to apply the model in a satisfactory manner. Our approach is therefore limited but it offers a first application of the model to this new environment and constitutes a stepping-stone for further development of the modelling approach for this bay. 
Other limitations of our model that should be mentioned are its systematic overestimation of growth during the autumnal period and an insufficient integration of inter-individual variability. The systematic tendency to overestimate growth could be due to a change in the physiology of scallops at the end of the reproductive season and period leading into winter. Specific ecophysiological experiments should be developed to address this question and improve the model. For the moment, we have applied an individual-based modelling strategy by introducing variability between individuals through the initial condition values. To account for more variability in physiological traits, similar studies, e.g. Thomas et al. (2015) and Bacher and Gangnery (2006) used specific model parameterization of the ingestion function for each individual. For instance, $X_{k}$ values were allocated to each individual following a Gaussian distribution. It would now be interesting to adapt a similar approach to the scallop DEB model.

Quantitative modelling of reproductive processes (preliminary storage phase, gametogenesis, spawning and/or resorption) is not easy as these processes are typically species-specific. There are no general rules on how to handle reproductive activity in DEB theory, especially regarding reproduction buffer dynamics. Bernard et al. (2011) introduced a fourth state variable in order to improve modelling of reproduction dynamics in the Pacific oyster, Crassostrea gigas. Numerous marine organisms from temperate waters spawn once or twice at a relatively fixed time each year (Gosling, 2004). For $P$. maximus, however, reproductive activity is more complex, with asynchronous spawning during a highly variable reproductive window. For this preliminary approach, however, we made the assumption that the mechanisms governing reproductive activity would be quite similar among bivalves and thus between oysters and scallops.

The reproductive cycle of $P$. maximus has been studied extensively in many places (e.g. Magnesen and Christophersen, 2008). Concerning our studied area, contrasting patterns were shown between the Bay of Brest and Bay of Saint-Brieuc (Paulet et al., 1995). Scallops in the Bay of Brest usually spawn between April and October, with a massive first spawning in April followed by a second maturation phase until July characterized by one or several smaller spawning events. A third summer maturation phase leads to a last major spawning event during August (Paulet et al., 1995). A late spawning event 
may be observed in autumn, but only in a few individuals (Saout et al., 2000). In the Bay of Brest, this seasonal cycle varies strongly between individuals, resulting in a lack of synchronism (Paulet et al., 1995). The results from our simulations, obtained over six years in the Bay of Brest, correspond fairly well to this description. More precisely, the model was able to partly simulate the observed asynchronicity between individuals, and the mechanisms implemented to trigger spawning appeared to be sufficiently relevant to simulate the onset of the first spawning, the temporal spawning window, and the number of spawning events (Fig. 6).

Paulet, 1990). Moreover, the seasonal cycle is known to be similar between individuals, showing a higher synchronism in this area than in the Bay of Brest (Paulet et al., 1988). Of course, the application of our model in the Bay of Saint-Brieuc is only a first attempt and suffers from a lack of forcing data. Nevertheless, it seems that the current version of the model was able to reproduce the different patterns of the reproductive cycle of P. maximus observed in this area. This tends to confirm that the environmental factors used here are the main key-drivers of reproduction processes of $P$. maximus. invertebrates, there is much evidence for the influence of exogenous factors (e.g. temperature, food and photoperiod) on the progress of gametogenesis and for regulation by endogenous rhythms on which environmental signals may act as synchronizers (e.g. Mat et al., 2014). Many environmental variables trigger such regulation but, most often, temperature and food availability (Franco et al., 2015; Ubertini et al, 2017) are considered to be the key factors. This is the case for bivalves, particularly pectinids (Lavaud et al. 2014). Scallops are sublittoral, epifaunal and active suspensionfeeding bivalves that rely on suspended detrital material, phytoplankton and microphytobenthos as their main food sources (Robert et al., 1994; Chauvaud et al., 2001). Saout et al. (1999) showed that, in $P$. maximus, a simultaneous increase of temperature and photoperiod enhanced gonad growth when food is not limiting. However, it was still not clear which of these two factors is the more influential. 
Our results obtained in the Bay of Brest show that, within a temporal photoperiod window, spawning is mainly triggered mainly by phytoplankton blooms once the GSI threshold is reached. In this eutrophic area, temperature might play a secondary role in terms of triggering spawning. For instance, in 2000 and 2002, the first bloom of the year was late compared with the other years (June 3 and May 14, respectively; Fig. 3). Accordingly, for both years, the model simulated a later occurrence of first spawning (June 4 and May 15, respectively; Fig. 7) that fitted well with field observations. By comparison, blooms of phytoplankton in the Bay of Saint-Brieuc were much lower than those observed in the Bay of Brest and presumably not a source of stress. Values were always below the threshold for triggering spawning. In this new environment, phytoplankton blooms were presumably not the trigger for spawning. Based on previous studies, we basically used a temperature threshold in this environment (Fifas, 2004) and the simulations obtained were in accordance with spawning processes observed in this bay.

In the last part of this study, we explored the potential consequences of climate change for the reproductive activity of $P$. maximus in northern Brittany. Predicting the temperature of the future atmosphere and oceans has been a focus of research for a few decades now. The evolution of food supply to organisms, which in the ocean starts with phytoplankton, is comparatively less well understood or predictable. Although the reliability of ocean primary production models is continually improving, predicting the future is challenging (Gradinger et al.,2009; Lavoie et al., 2017) for coastal environments. In this context, we believe that our approach, consisting of transposing current food availability time series to future scenarios, is valuable because it allows a greater degree of complexity in predictions as it provides realistic estimates of inter-annual variability. This approach could be complemented by simulations under enhanced phytoplankton productivity, as predicted by recent modelling (Jensen et al., 2017). Only the most extreme scenario (RCP8.5) revealed contrasting predictions with the current one. While distinct reproductive cycles are currently observed between the Bay of Brest and the Bay of Saint-Brieuc, it seems that future environmental conditions would generally extend the spawning period, with an additional spawning event predicted in both locations. However, contrasted impacts also emerged when comparing simulations obtained for the two bays. An 
564 increase in seawater temperature advanced the onset of spawning by 20 to 44 days in the Bay of Saint-

565 Brieuc, irrespective of the phytoplankton scenario, while the spawning timeline in the Bay of Brest

566 was unchanged. Warmer temperatures might also lead to better recruitment. Shephard et al. (2010)

567 found that the mean annual recruitment of young scallops in the Isle of Man was positively related to

568 spring water temperature. Adult gonads were also larger, indicating higher egg production during

569 warmer years. Our simulations led to similar conclusions, showing that an increase in seawater

570 temperature combined with adequate food supply could well enhance scallop recruitment by: (1)

571 increasing the spawning window in late summer and (2) advancing the onset of spawning in spring in

572 the Bay of Saint-Brieuc. 


\section{Acknowledgements}

A grant from Région Bretagne and the University of Western Brittany (UBO) supported MG

575 during her PhD work. The authors are grateful to the IUEM staff of the EVECOS networks, the

576 IFREMER staff of the REPHY network and the staff of the SOMLIT network, through which all the

577 field data were gathered. We also thank Helen McCombie-Boudry of the Translation Bureau of the

578 University of Western Brittany for improving the English of this manuscript. 


\section{References}

581

582

583

584

585

586

587

588

589

590

591

592

593

594

595

596

597

598

599

600

601

602

603

604

605

606

607

608

609

610

Alunno-Bruscia, M., Bourlès, Y., Maurer, D., Robert, S., Mazurié, J., Gangnery, A., Goulletquer, P.,Pouvreau, S. (2011). A single bio-energetics growth and reproduction model for the oyster Crassostrea gigas in six Atlantic ecosystems. J. Sea Res. 66, 340-348.

Ansell, A. D. (1991). Three European scallops: Pecten maximus, Chlamys (Aequipecten) opercularis and C.(Chlamys) varia. Scallops: Biology, Ecology and Aquaculture, 715-751.

Bacher, C. \& Gangnery, A. (2006). Use of Dynamic Energy Budget and Individual Based models to simulate the dynamics of cultivated oyster populations. J. Sea Res. 56, 140-155. http://doi:10.1016/j.seares.2006.03.004

Bayne, B. L., Hawkins, A. J. S., \& Navarro, E. (1987). Feeding and digestion by the mussel Mytilus edulis L.(Bivalvia: Mollusca) in mixtures of silt and algal cells at low concentrations. Journal of Experimental Marine Biology and Ecology, 111(1), 1-22.

Belin, C. and co-authors (2017). REPHY - French Observation and Monitoring program for Phytoplankton and Hydrology in coastal waters (2017). REPHY dataset - French Observation and Monitoring program for Phytoplankton and Hydrology in coastal waters. 1987-2016 Metropolitan data. SEANOE. http://doi.org/10.17882/47248

Bernard, I., de Kermoysan, G., Pouvreau, S. (2011). Effect of phytoplankton and temperature on the reproduction of the Pacific oyster Crassostrea gigas: investigation through DEB theory. J. Sea Res. 66, 349-360.

Beukema, J. J., Dekker, R., Jansen, J. M. (2009). Some like it cold: populations of the tellinid bivalve Macoma balthica (L.) suffer in various ways from a warming climate. Marine Ecology Progress Series, 384, 135-145.

Chauvaud, L., Thouzeau, G., Paulet, Y.M. (1998). Effects of environmental factors on the daily growth rate of Pecten maximus juveniles in the Bay of Brest (France). J. Exp. Mar. Biol. Ecol. $227,83-111$.

Chauvaud, L., Donval, A., Thouzeau, G., Paulet, Y.M., Nézan, E. (2001). Variations in food intake of Pecten maximus (L.) from the Bay of Brest (France): influence of environmental factors and phytoplankton species composition. C. R. Acad. Sci. III 324, 743-755.

Chauvaud, L., Patry, Y., Jolivet, A., Cam, E., Le Goff, C., Strand, Ø., Charrier, G., Thébault, J., Lazure, P., Gotthard, K., Clavier, J. (2012). Variation in size and growth of the great scallop Pecten maximus along a latitudinal gradient. PLoS ONE 7, e37717. 
Claereboudt, M. R., \& Himmelman, J. H. (1996). Recruitment, growth and production of giant scallops (Placopecten magellanicus) along an environmental gradient in Baie des Chaleurs, eastern Canada. Marine Biology, 124(4), 661-670.

Devauchelle, N., \& Mingant, C. (1991). Review of the reproductive physiology of the scallop, Pecten maximus, applicable to intensive aquaculture. Aquatic Living Resources, 4(1), 41-51.

Emmery, A. (2008). Modélisation de la croissance et de la reproduction de la coquille Saint-Jacques Pecten maximus selon la théorie «Dynamic Energy Budget»: variabilité environnementale et croissance individuelle. Univeristy of Western Brittany (Master thesis).

Fifas, S. (2004). La coquille Saint-Jacques en Bretagne. Rapport Ifremer. Direction des Ressources Vivantes. Ressources Halieutiques. 14p.

Foveau A., Foucher E., Desroy N., (2013). Identification biogéographique des gisements de coquilles Saint-Jacques en Manche. Réunion finale du projet ANR CoManche. Caen, France. 10-11 décembre 2013.

Franco, C., Aldred, N., Sykes, A. V., Cruz, T., Clare, A. S (2015). The effects of rearing temperature on reproductive conditioning of stalked barnacles (Pollicipes pollicipes). Aquaculture, vol 448, 410-417. Doi:10.1016/j.aquaculture.2015.06.015

Gosling, E. (2004). Bivalve Molluscs. Biology, Ecology and Culture. Edition Fishing News Books. $444 \mathrm{p}$.

Gourault, M., Petton, S., Thomas, Y., Pecquerie, L., Marques, G.M., Cassou, C., Fleury, E., Paulet, Y M., Pouvreau, S (submitted, this issue). Modelling reproductive traits of an invasive bivalve species under contrasted climate scenarios from 1960 to 2100. Journal of Sea Research.

Gradinger, R. (2009). Sea-ice algae: Major contributors to primary production and algal biomass in the Chukchi and Beaufort Seas during May/June 2002. Deep Sea Research Part II: Topical Studies in Oceanography, 56(17), pp.1201-1212.

Guerin, L. (2004). La crépidule en Rade de Brest: un modèle biologique d'espèce introduite proliférante en réponse aux fluctuations de l'environnement. University of Western Brittany $(\mathrm{PhD}$ thesis).

ICES, (2015). Report of the Scallop Assessment Working Group (WGScallop), 6-10 October 2014, Nantes, France. ICES CM 2014\ACOM:24. 35 pp.

IPCC, (2014). Climate Change 2014: Synthesis Report. Contribution of Working Groups I, II and III to the Fifth Assessment Report of the Intergovernmental Panel on Climate Change [Core Writing Team, R.K. Pachauri and L.A. Meyer (eds.)]. IPCC, Geneva, Switzerland, 151 pp. 
Jensen, L.Ø., Mousing, E.A. and Richardson, K. (2017). Using species distribution modelling to predict future distributions of phytoplankton: Case study using species important for the biological pump. Marine Ecology, 38(3).

Kooijman, S.A.L.M. (2010). Dynamic Energy Budget Theory for Metabolic Organization. Cambridge Ed., University Press, Cambridge, UK.

Lavaud, R., Flye-Sainte-Marie, J., Jean, F., Emmery, A., Strand, O., Kooijman, S.A.L.M. (2014). Feeding and energetics of the great scallop, Pecten maximus, through a DEB model. Journal of Sea Research, vol 94, 5-18.

Lavoie, D., Lambert, N. and Gilbert, D. (2017). Projections of Future Trends in Biogeochemical Conditions in the Northwest Atlantic Using CMIP5 Earth System Models. Atmosphere-Ocean, pp.1-23.

Leynaert, A. (2016). Observatoire de l'Institut Universitaire et Européen de la Mer, série Microalgues. https $/ / \mathrm{www}$-iuem. univ-brest.fr/observatoire/observation-cotiere/faune-flore/microalgues

Lorrain, A., Paulet, Y.M., Chauvaud, L., Savoye, N., Nézan, E., Guérin, L. (2000). Growth anomalies in from coastal waters (Bay of Brest, France): relationship with diatom blooms. J. Mar. Biol. Assoc. UK 80, 667-673.

Lorrain, A., Paulet, Y.M., Chauvaud, L., Savoye, N., Donval, A., Saout, C. (2002). Differential $\delta 13 C$ and $\delta 15 \mathrm{~N}$ signatures among scallop tissues: implications for ecology and physiology. J. Exp. Mar. Biol. Ecol. 275, 47-61.

Magnesen, T. \& Christophersen, G. (2008). Reproductive cycle and conditioning of translocated scallops (Pecten maximus) from five broodstock populations in Norway. Aquaculture, 285(1), 109-116.

Marchais, V. (2014). Relations trophiques entre producteurs primaires et quatre consommateurs primaires benthiques dans un écosystème côtier tempéré. University of Western Brittany $(\mathrm{PhD}$ thesis).

Mason, J. (1957). The age and growth of the scallop, Pecten maximus (L.), in Manx waters. J. Mar. Biol. Assoc. U. K. 36, 473-492.

Mat, A., Massabuau, J.C., Ciret, P., Tran, D. (2014). Looking for the clock mechanism responsible for circatidal behavior in the oyster Crassostrea gigas. Marine Biology, vol 161, issue 1, 89-99.

Menge, B.A., Chan, F., Nielsen, K.J., Lorenzo, E.D. \& Lubchenco, J. (2009) Climatic variation alters supply-side ecology: impact of climate patterns on phytoplankton and mussel recruitment. Ecological Monographs, 79, 379-395. doi:10.1890/08-2086.1 
Montalto, V., Martinez, M., Rinaldi, A., Sarà, G. \& Mirto, S. (2017). The effect of the quality of diet on the functional response of Mytilus galloprovincialis (Lamarck, 1819): Implications for integrated multitrophic aquaculture (IMTA) and marine spatial planning. Aquaculture 468, 371377. doi:10.1016/j.aquaculture.2016.10.030

Morgan, E., O' Riordan, R.M. \& Culloty, S.C. (2013) Climate change impacts on potential recruitment in an ecosystem engineer. Ecology and Evolution, 3, 581-94. doi:10.1002/ece3.419

Paulet, Y. M. (1990). Rôle de la reproduction dans le déterminisme du recrutement chez Pecten maximus (L) de la baie de Saint-Brieuc. University of Western Brittany ( $\mathrm{PhD}$ thesis).

Paulet, Y. M., Lucas, A., Gerard, A. (1988). Reproduction and larval development in two Pecten maximus (L.) populations from Brittany. Journal of Experimental Marine Biology and Ecology, 119(2), 145-156.

Paulet, Y. M., Bekhadra, F., Devauchelle, N., Donval, A., Dorange, G. (1995). Cycles saisonniers, reproduction et qualité des ovocytes chez Pecten maximus en rade de Brest. In 3e Rencontres Scientifiques Internationales du contrat de baie de la rade de Brest. Brest 14-16 mars 1995.

Paulet, Y.M., Bekhadra, F., Devauchelle, N., Donval, A., Dorange, G. (1997). Seasonal cycles, reproduction and oocyte quality in Pecten maximus from the Bay of Brest. Ann. Inst. Océanogr. $73,101-112$.

R Core Team (2017). A language and environment for statistical computing. R Foundation for Statistical Computing, Vienna, Austria.

Robert, R.,Moal, J., Campillo,M.J., Daniel, J.Y., (1994). The food value of starch rich flagellates for Pecten maximus (L.) larvae. Preliminary results. Haliotis 23, 169-710.

Salomon, J.C., Breton, M. (1991). Numerical study of the dispersive capacity of the Bay of Brest, France, towards dissolved substances. In: Environmental hydraulics, Lee and Cheung, editors, Balkema, Rotterdam, pp. 459-464.

Saout, C., Quéré, C., Donval, A., Paulet, Y.M., Samain, J.F., (1999). An experimental study of the combined effects of temperature and photoperiod on reproductive physiology of Pecten maximus from the Bay of Brest (France). Aquaculture 172, 301-314.

Saout, C. (2000). Contrôle de la reproduction chez Pecten maximus (L.) : études in situ et expérimentales. University of Western Brittany ( $\mathrm{PhD}$ thesis).

Saraiva, S., van der Meer, J., Kooijman, S.A.L.M., Sousa, T., (2011). DEB parameters estimation for Mytilus edulis. J. Sea Res. 66 (4), 289-296. 
Shephard, S., Beukers-Stewart, B., Hiddink, J. G., Brand, A. R., Kaiser, M. J. (2010). Strengthening recruitment of exploited scallops Pecten maximus with ocean warming. Marine Biology, 157(1), 91-97.

Shumway, E.S. (1990). A review of the effects of algal blooms on shellfish and aquaculture. Journal of the world aquaculture society, 21(2), 65-104.

Soudant, P., Marty, Y., Moal, J., Robert, R., Quéré, C., Le Coz, J. R., Samain, J. F. (1996). Effect of food fatty acid and sterol quality on Pecten maximus gonad composition and reproduction process. Aquaculture, 143(3-4), 361-378.

Strohmeier, T., Strand, Ø., Cranford, P., (2009). Clearance rates of the great scallop Pecten maximus and blue mussel Mytilus edulis at low natural seston concentrations. Mar. Biol. 156 (9), 17811795.

Taylor, K.E. (2001) Summarizing multiple aspects of model performance in a single diagram. Journal of Geophysical Research: Atmospheres, 106, 7183-7192.

Thomas, Y., Pouvreau, S., Alunno-Bruscia, M., Barillé, L., Gohin, F., Bryère, P. \& Gernez, P. (2016) Global change and climate-driven invasion of the Pacific oyster (Crassostrea gigas) along European coasts: A bioenergetics modelling approach. Journal of Biogeography, 43, 568-579. doi:10.1111/jbi.12665

Ubertini, M., Lagarde, F., Mortreux, S., Le Gall, P., Chiantella, C., Fiandrino, A., Bernard, I., Pouvreau, S., Roque d'Orbcastel, E. (2017). Pacific oyster Crassostrea gigas in the Thau lagoon: Evidence of an environment-dependent strategy. Aquaculture, vol. 473, 51-61. doi:10.1016/j.aquaculture.2017.01.025

van Vuuren, D.P., Edmonds, J., Kainuma, M. et al. (2011) The representative concentration pathways: an overview. Climatic Change, 109-5. doi:10.1007/s10584-011-0148-z

Valdizan, A., Beninger, P. G., Decottignies, P., Chantrel, M. \& Cognie, B. (2011) Evidence that rising coastal seawater temperatures increase reproductive output of the invasive gastropod Crepidula fornicata. Marine Ecology Progress Series, 438, 153-165. 
733

\section{Appendix}

Appendix A: Details on climatic projections models used and additional figures (Fig. A.1 and A.2) and tables (Table A.1 and A.2).

In this study we used temperature scenarios resulting from Representative Concentration Pathways (RCP) models, the latest generation of scenarios that provide inputs to climate models. The purpose of using scenarios is not to predict the future, but to explore both the scientific and real-world implications of different plausible futures (van Vuuren et al., 2011). The IPCC authors chose four carbon dioxide $\left(\mathrm{CO}_{2}\right)$ emission trajectories to focus on and labeled them based on how much heating they would result in at the end of the century: $2.6,4.5,6$ and 8.5 watts per square meter $\left(\mathrm{W} \mathrm{m}^{-2}\right)$. Fig. A. 1 shows the annual $\mathrm{CO}_{2}$ emissions (in billions of tons of carbon) until 2100 for each of the RCPs.

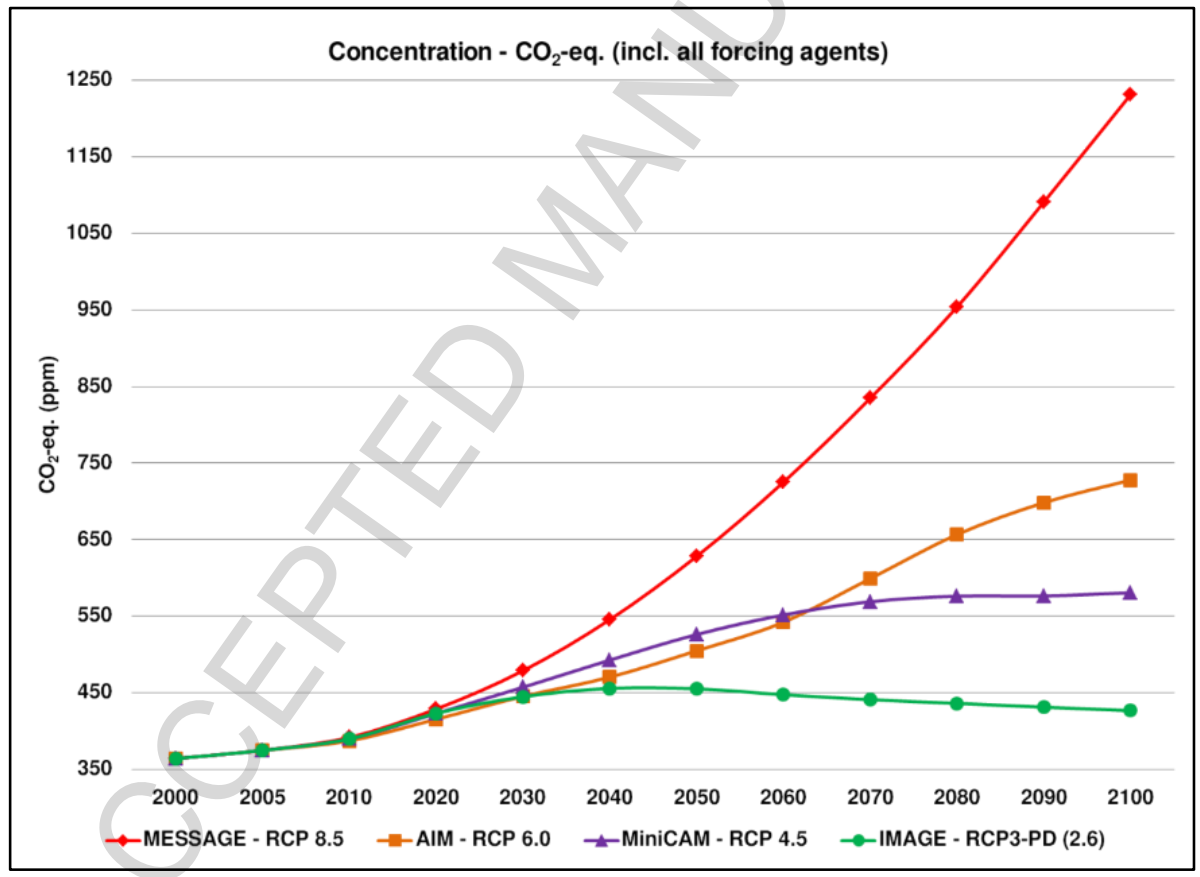

Fig. A.1: Emissions of annual $\mathrm{CO}_{2}$ across the RCPs. The RCP2.6 scenario (IMAGE-RCP3-PD(2.6)) and the RCP8.5 scenario (MESSAGE-RCP8.5) represent extreme situations: RCP2.6 is the most optimistic and RCP8.5 is the most drastic warming. Source: IPCC Fifth Assessment Report (2014).

In the $2.6 \mathrm{~W} \mathrm{~m}^{-2}$ scenario (RCP2.6), greenhouse-gas emissions drop to zero by about 2070, and then continuing to fall, so that the world's emissions would become negative - actually withdrawing greenhouse gases from the air and locking them away — for decades. This pushes the bounds of what 
is plausible through mitigation, some experts say. At the high end, in the $8.5 \mathrm{~W} \mathrm{~m}^{-2}$ scenario

751 (RCP8.5), $\mathrm{CO}_{2}$ levels would soar beyond 1,300 parts per million by the end of the century and continue to rise rapidly (Table A.1).

Table A.1: Description of $\mathrm{CO}_{2}$ emissions scenarios used by IPCC authors (van Vuuren et al., 2011).

\begin{tabular}{|l|l|}
\hline Scenario & \multicolumn{1}{|c|}{ Description } \\
\hline RCP8.5 & Rising radiative forcing pathway leading to $8.5 \mathrm{~W} \mathrm{~m}^{2}\left(\sim 1370 \mathrm{ppm} \mathrm{CO}_{2}\right.$ eq $)$ by 2100. \\
\hline RCP6 & $\begin{array}{l}\text { Stabilization without overshoot pathway to } 6 \mathrm{~W} \mathrm{~m}^{2}\left(\sim 850 \mathrm{ppm} \mathrm{CO}_{2} \text { eq }\right) \text { at stabilization } \\
\text { after } 2100 .\end{array}$ \\
\hline RCP4.5 & $\begin{array}{l}\text { Stabilization without overshoot pathway to } 4.5 \mathrm{~W} \mathrm{~m}^{2}\left(\sim 650 \mathrm{ppm} \mathrm{CO}_{2} \text { eq) at stabilization }\right. \\
\text { after 2100. }\end{array}$ \\
\hline RCP2.6 & $\begin{array}{l}\text { Peak in radiative forcing at } \sim 3 \mathrm{~W} \mathrm{~m}^{2}\left(\sim 490 \mathrm{ppm} \mathrm{CO}_{2} \text { eq }\right) \text { before } 2100 \text { and then decline (the } \\
\left.\text { selected pathway declines to } 2.6 \mathrm{~W} \mathrm{~m}^{2} \text { by } 2100\right) .\end{array}$ \\
\hline
\end{tabular}

Atmospheric temperature data were obtained from the CERFACS modeling center. For each scenario (RCP2.6 and RCP8.5) 14 models were available (http://cmippcmdi.llnl.gov/cmip5/availability.html; Table A.2). To know which model was the most comparable to our historical temperature data in the Bay of Brest and the Bay of Saint Brieuc, we used the diagram of taylor (Fig. A.2) in order to compare monthly air temperature since 1960 to nowadays in our bays with monthly air temperature from the 14 models during the same period. Among the 14 models, the CNRM-CM5 model was the best (Fig. A.2).

Table A.2: Description of the 14 models available for the study.

\begin{tabular}{|l|l|c|l|}
\hline Modeling Center & \multicolumn{1}{|c|}{ Model } & $\mathrm{N}^{\circ}$ & \multicolumn{1}{|c|}{ Institution } \\
\hline BCC & BCC-CSM1.1 & 1 & Beijing Climate Center \\
\hline CCCma & CanESM2 & 2 & $\begin{array}{l}\text { Canadian Centre for Climate Modelling and } \\
\text { Analysis }\end{array}$ \\
\hline NCAR & CCSM4 & 3 & National Center for Atmospheric Research \\
\hline NSF-DOE-NCAR & CESM1(CAM5) & 4 & $\begin{array}{l}\text { National Science Foundation, Department of } \\
\text { Energy, National Center for Atmospheric Research }\end{array}$ \\
\hline $\begin{array}{l}\text { CNRM- } \\
\text { CERFACS }\end{array}$ & CNRM-CM5 & & $\begin{array}{l}\text { Centre National de Recherches Météorologiques / } \\
\text { Centre Européen de Recherche et Formation } \\
\text { Avancées en Calcul Scientifique }\end{array}$ \\
\hline LASG-IAP & FGOALS-g2 & 6 & LASG, Institute of Atmospheric Physics \\
\hline NOAA GFDL & GFDL-CM3 & 7 & Geophysical Fluid Dynamics Laboratory \\
\hline INPE & HadGEM2-ES & 8 & Instituto Nacional de Pesquisas Espaciais \\
\hline IPSL & IPSL-CM5A-LR & 9 & Institut Pierre-Simon Laplace \\
\hline & IPSL-CM5A-MR & 10 & \\
\hline MPI-M & MPI-ESM-LR & 11 & Max Planck Institute for Meteorology \\
\hline
\end{tabular}




\begin{tabular}{|l|l|c|l|}
\hline & MPI-ESM-MR & 12 & \\
\hline MRI & MRI-CGCM3 & 13 & Meteorological Research Institute \\
\hline NCC & NorESM1-M & 14 & Norwegian Climate Centre \\
\hline
\end{tabular}

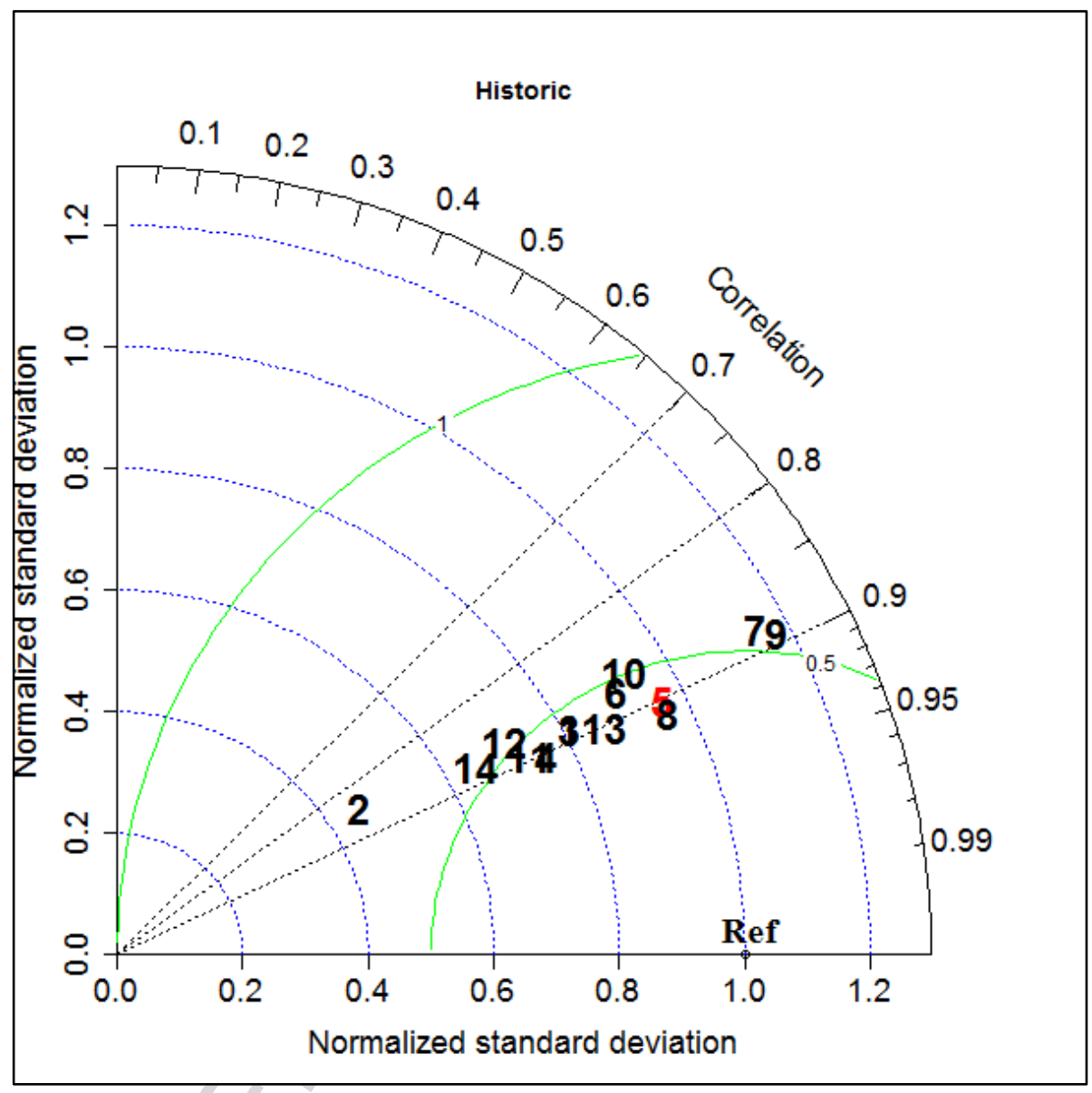

Fig. A.2: Taylor diagram giving the Pearson's correlation coefficient, the centered root mean squared difference and the normalized standard deviation between historical air temperature observed in the

Bay of Brest since 1960 (Ref) and air temperature predicted by 14 different models (see Table above; 